\title{
$\gamma$-Ray Irradiation Effect on MCF Rubber Solar Cells with both Photovoltaics and Sensing Involving Semiconductors Fabricated under Magnetic and Electric Fields
}

\author{
Kunio Shimada $^{1 *}$ (), Ryoju Kato ${ }^{1}$, Ryo Ikeda², Hiroshige Kikura ${ }^{2}$, Hideharu Takahashi² \\ ${ }^{1}$ Department of Symbiotic Systems Sciences, Fukushima University, Fukushima, Japan \\ ${ }^{2}$ Research Laboratory for Nuclear Reactors, Tokyo Institute of Technology, Tokyo, Japan \\ Email: *shimadakun@sss.fukushima-u.ac.jp, s1710046@ipc.fukushima-u.ac.jp, ikeda.r.ah@m.titech.ac.jp, \\ kikura@lane.iir.titech.ac.jp, htakahashi@lane.iir.titech.ac.jp
}

How to cite this paper: Shimada, K., Kato, R., Ikeda, R., Kikura, H. and Takahashi, H. (2020) $\gamma$-Ray Irradiation Effect on MCF Rubber Solar Cells with both Photovoltaics and Sensing Involving Semiconductors Fabricated under Magnetic and Electric Fields. World Journal of Mechanics, 10, 95-119. https://doi.org/10.4236/wjm.2020.108008

Received: August 17, 2020

Accepted: August 28, 2020

Published: August 31, 2020

Copyright $\odot 2020$ by author(s) and Scientific Research Publishing Inc. This work is licensed under the Creative Commons Attribution International License (CC BY 4.0).

http://creativecommons.org/licenses/by/4.0/

\section{(c) (i) Open Access}

\begin{abstract}
For cases in which a robot with installed solar cells and a sensor operates in a nuclear reactor building or in space for extravehicular activity, we require elastic and extensible solar cells. More than two different types of sensing are also required, minimally with photovoltaics and built-in electricity. Magnetic compound fluid (MCF) rubber solar cells are made of rubber, so they are elastic and extensible as well as sensitive. To achieve flexibility and an effective photovoltaic effect, MCF rubber solar cells must include both soluble and insoluble rubbers, $\mathrm{Fe}_{3} \mathrm{O}_{4}, \mathrm{TiO}_{2}, \mathrm{Na}_{2} \mathrm{WO}_{4} \cdot 2 \mathrm{H}_{2} \mathrm{O}$, etc. On the basis of this constitution, we propose a consummate fabrication process for MCF rubber solar cells. The characteristics of these cells result from the semiconductor-like role of the molecules of $\mathrm{TiO}_{2}, \mathrm{Fe}_{3} \mathrm{O}_{4}, \mathrm{Ni}, \mathrm{Na}_{2} \mathrm{WO}_{4} \cdot 2 \mathrm{H}_{2} \mathrm{O}$, polydimethylsiloxane (PDMS), natural rubber (NR), oleic acid, polyvinyl alcohol (PVA), water and magnetic cluster involved in the MCF rubber. Their tendencies can be deduced by synthesizing knowledge about the enhancement of the reverse-bias saturation current $I_{S}$ and the diode ideality factor $N$, with conventional knowledge about the semiconductor affected by $\gamma$-irradiation and the attenuation of the photon energy of $\gamma$-rays.
\end{abstract}

\section{Keywords}

$\gamma$-Irradiation, Irradiation Effect, Rubber, Magnetic Compound Fluid (MCF), Electrolytic Polymerization, Photovoltaics, Solar Cells, Magnetic Fluid, Natural Rubber, Silicone Rubber, Aggregation, Magnetic Field, Sensor, Piezo-Electricity, Built-in Electricity, Induced Voltage, Adhesion, Magnetic Cluster, Robot 


\section{Introduction}

Elastic and extensible solar cells are highly desirable in robots with installed solar cells and a sensor operating in a nuclear reactor building or in space for extravehicular activity. In the future, robots will substitute for humans more and more to carry out activities in hazardous circumstances. The robot should have more than two types of sensing, minimally with photovoltaics and built-in electricity. In addition, the sensor or solar cells must be elastic and extensible. The robot needs to be able to sense force, temperature, etc. Photovoltaics allow for free activity with a battery, making the robot independent of any external power source or electric wires. Independent sensors run on an external power source such as built-in electricity can function as piezo-materials. In order to achieve both elasticity and extensibility, rubber is the best material. Thus, rubber should be used to develop materials or elements for sensing, photovoltaics and built-in electricity. We propose elastic and extensible solar cells with sensing capabilities for force and $\gamma$-ray irradiation, and with built-in electricity, built-in voltage and built-in current [1]. By applying both DC electric and magnetic fields to a water-soluble rubber latex such as natural rubber (NR) or chloroprene rubber (CR) compounded with our developed magnetic responsive fluid, a magnetic compound fluid (MCF), the MCF rubber liquid can be electrolytically polymerized to form a solid [2]. A bulk heterostructure of magnetic clusters is formed in the MCF rubber. The magnetic clusters involved in the magnetic and metal particles of the MCF are many thin-rod like shape [3]. MCF has nm-ordered magnetite $\left(\mathrm{Fe}_{3} \mathrm{O}_{4}\right)$ particles and $\mu$ m-ordered metal particles such as $\mathrm{Ni}, \mathrm{Fe}$, etc. [4]. The electrolytically polymerized MCF rubber has the properties of both piezo-resistivity and piezo-electricity [5]. As for the latter, the induced voltage is related to piezo-electricity that is evaluated as built-in electricity, built-in voltage and current. The built-in electricity occurs due to ionized molecules and particles of the rubber latex, oleic acid coated around $\mathrm{Fe}_{3} \mathrm{O}_{4}$ of magnetic fluid (MF), and water, all of which together play the roles of an acceptor-like p-type semiconductor (corresponding to $\mathrm{A}^{-}$) and of a donor-like $\mathrm{n}$-type semiconductor (corresponding to $\mathrm{D}^{+}$), as discussed in our previous studies [6] [7]. Given its semiconductor-like role, the MCF rubber is also photovoltaic [6]. In addition, due to the elasticity and extensibility of NR or CR, the MCF rubber satisfies the above-mentioned prerequisites and we can therefore expect it to be suitable for use in a nuclear reactor building or in space for extravehicular activity.

Regarding ordinary solar cells used in space, solar cells have seen considerable use in power sources installed on telecommunications satellites, in armaments, and in equipment used for meteorological or scientific research. Space environments are especially severe because of radiation exposure, which may induce lattice defects in solar cells or generate transient effects depending on the extent of the enhancement of electron-hole (e-h) pairs [8] [9]. These defects and effects due to irradiation lead to the degradation or metamorphosis of semiconductors. Semiconductors are basic not only to solar cells but also to photodetectors, metal 
semiconductors (MSs), metal insulator semiconductors (MISs), and metal oxide semiconductors (MOSs). Recent research has examined the effects of irradiation on solar cells [10], MIS solar cells [11], photodetectors [12], MS Schottky diodes [13], MIS Schottky diodes [14], MOS capacitors [15] [16], and MOS diodes [17]. In space, irradiation is defined by a linear energy transfer (LET) in which energy is transferred to a material by ionization when radiation passes through the material during unit length. Types of radiation with low LET include X-rays, $\gamma$-rays and electron beams, while those with high LET include proton beams and heavy particle beams. Low-LET radiation induces a total ionizing dose (TID) effect generated by ionization under excessive incident radiation so that the threshold level of voltage changes and mutual conductance decreases, while high-LET radiation induces a single-event (SE) effect generated by the creation of high density electric charges under ionization at the incident single particle so that an overcurrent is generated in the electric circuit, causing a malfunction.

As in the case of solar cells used in space, the above-mentioned irradiation effects must also be taken into account in the case of solar cells used in a nuclear reactor building. Therefore, in the present study, we investigated $\gamma$-ray irradiation effects on elastic and extensible MCF rubber solar cells with an eye to their use in elastic and extensible MCF rubber sensors proposed for engineering production. MCF rubber solar cells are produced by a consummate fabrication process, which includes our proposed novel adhesion technique to solve the problem of adhesion between rubber and metal electrodes [18]. The current commercial conductive adhesive provides electrical insulation with degrading conductivity between rubber and electrodes. In contrast, under our proposed novel adhesion technique, MCF rubber with a metal complex hydrate is electrolytically polymerized under the application of a magnetic field so that electrodes can be adhered to the rubber. The hybrid MCF rubber used in sensors and solar cells discussed in our previous study was produced using only water-soluble NR or CR. To the best of our knowledge, MCF rubber made of water-insoluble materials has not yet been investigated. It is necessary to drop dye and electrolytes on each MCF rubber surface so that the photovoltaics degrade due to aridity. Therefore, in order to resolve their aridity, in the present consummate fabrication process, we have adopted a method in which water-soluble and water-insoluble rubbers are mixed to be electrolytically polymerized by an emulsifier such as polyvinyl alcohol (PVA) [19], and dye and electrolytes are involved in the MCF rubber beforehand [20]. We also investigated the photovoltaic and $\gamma$-irradiation effects on the MCF rubber using knowledge previously obtained on MS, MIS and MOS [8]-[17].

\section{Fabrication of MCF Rubber Solar Cells}

\subsection{Photovoltaics}

The consummate fabrication process of MCF rubber solar cells includes three basic configurations: 1) a novel adhesion technique [18], 2) electrolytic polyme- 
rization of rubber mixed with water-soluble and water-insoluble rubbers [19], and 3) permeation of liquid to rubber [20] as follows:

1) When diene rubber latex with $C=C$ bonds such as NR or $C R$ compounded with a metal complex hydrate touched by a metal such as stainless steel, iron or lead, is electrolytically polymerized under a magnetic field, the solidified rubber and the metal adhere. When thin silver-gilt electric wires approximately $\phi 0.1$ $\mathrm{mm}$ in diameter are inserted in an MCF rubber consisting of $\mu \mathrm{m}$-ordered $\mathrm{Ni}$ particles with bumps on the surface, water-based MF with $\mathrm{Fe}_{3} \mathrm{O}_{4}, \mathrm{NR}$ and $\mathrm{CR}$, the wires cannot be detached through the MCF rubber, even though there are few thin silver-gilt wires and their diameter is very small, as shown in Figure A1 in Appendix [18]. The recommended hydrate is a metallic complex with more than two valency: $\mathrm{Na}_{2} \mathrm{WO}_{4} \cdot 2 \mathrm{H}_{2} \mathrm{O}$.

2) Water-soluble rubber (or diene rubber) such as NR and $C R$, and water-insoluble rubber (or non-diene rubber) such as silicone rubber $(\mathrm{Q})$ and urethane rubber $(\mathrm{U})$, are mixed to be electrolytically polymerized by an emulsifier such as PVA.

3) Although ordinary solid rubber such as NR or Q cannot be doped by any reagents directly because a solid rubber is generally impermeable, water can permeate MCF rubber, which can therefore be permeated by dopants whether the MCF rubber is water soluble or a combination of water-soluble and water-insoluble rubbers (see Figure A2 in Appendix) [20].

In advance of developing the consummate fabrication process, we investigated the photovoltaic effects of PVA, Q, and $\mathrm{Na}_{2} \mathrm{WO}_{4} \cdot 2 \mathrm{H}_{2} \mathrm{O}$, which are used in the process, because to the best of our knowledge, their effects had not been extensively investigated.

Regarding (2) above, we investigated the effects of the emulsifier PVA and the water-insoluble rubber $\mathrm{Q}$ on the photovoltaics. The constituents of the MCF rubber we used are shown in Table 1. The Q used in the present study was KF96 (1000 cSt, Shin-Etsu Chemical Co., Ltd., Tokyo, Japan), which is a pure silicone oil with polydimethylsiloxane (PDMS) as the methyl group without any silane, and which does not solidify to silicone rubber when a curing agent is used. S-500 (Regitex Co., Ltd., Atsugi, Japan) is an NR-latex including sulfur and $671 \mathrm{~A}$ is a CR-latex (Showa Denko Co., Ltd., Tokyo, Japan). MF is 40 wt $\% \mathrm{Fe}_{3} \mathrm{O}_{4}$ (W-40; Ichinen Chemicals Co., Ltd., Shibaura, Japan). $\mathrm{TiO}_{2}$ is anatase type (FUJIFILM Wako Pure Chemical Co., Ltd., Osaka, Japan) and is generally used in ordinary solar cells fields. MCF Rubbers 1 and 2 are compared with Rubbers 3 and 4, in

Table 1. Constituents of the MCF rubbers in Figure 1.

\begin{tabular}{|c|c|}
\hline & Constitution \\
\hline MCF rubber 1 & KF96: 3 g; S-500: 3 g; 671A: 3 g; PVA: 3 g; MF: 0.75 g; TiO $_{2}: 0.5$ g \\
\hline MCF rubber 2 & KF96: 3 g; S-500: 3 g; 671A: 3 g; PVA: 3 g; MF: 0.75 g \\
\hline MCF rubber 3 & S500: $3 \mathrm{~g}$; 671A: $3 \mathrm{~g}$; MF: $0.75 \mathrm{~g} ; \mathrm{TiO}_{2}: 0.5 \mathrm{~g}$ \\
\hline MCF rubber 4 & S500: $3 \mathrm{~g} ; 671 \mathrm{~A}: 3 \mathrm{~g}$; MF: $0.75 \mathrm{~g}$ \\
\hline
\end{tabular}




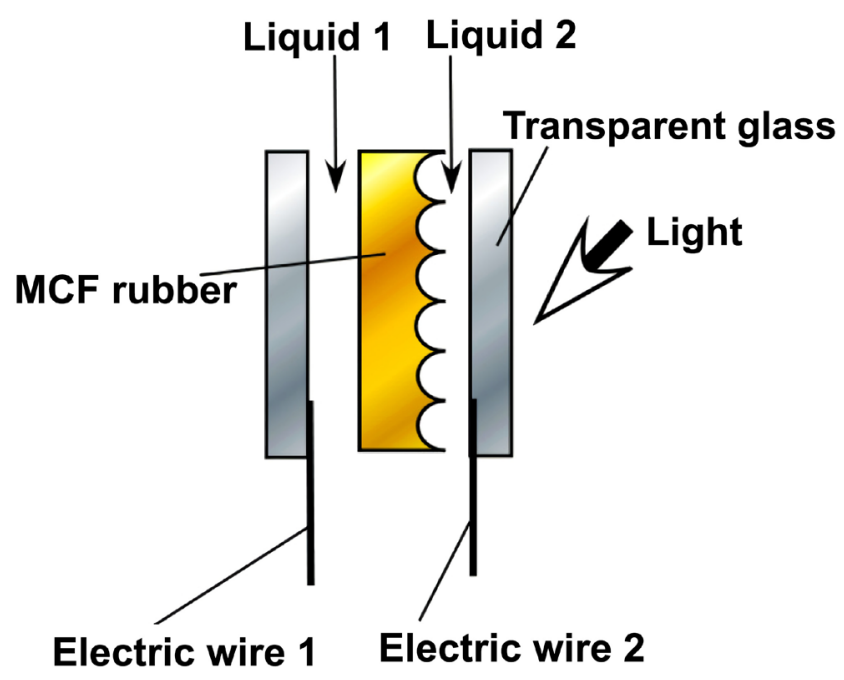

Figure 1. Experimental set-up to measure voltage.

which a water-soluble rubber such as NR or CR is used. These combined liquids were electrolytically polymerized by applying a static 312-mT magnetic field to a pair of stainless electrodes with a 1-mm gap using permanent magnets as paired opposites via the application of a constant electric field at $30 \mathrm{~V}$ for MCF Rubbers 1 and 2 and $6 \mathrm{~V}$ for MCF Rubbers 3 and 4, and $2.7 \mathrm{~A}$ and $5 \mathrm{~min}$ for all samples. The results of previous studies [2] [19] have identified $312 \mathrm{mT}, 6 \mathrm{~V}, 30 \mathrm{~V}$, and $2.7 \mathrm{~A}$ as the optimal values under a 1-mm electrode gap using permanent magnets. We used a 700-Lux ultraviolet light to illuminate MCF rubber sandwiched between sheets of conductive transparent glass (Figure 1), and the voltage between electric wires 1 as a cathode and 2 as an anode was measured (Figure 2). The surface of the MCF rubber that touches the transparent glass is convex-concave, as shown in Figure 1, because the electrolytically polymerized MCF rubber surface on the anode side takes on this shape due to the electrolytic polymerization [2]. Liquids 1 and 2 were poured on both the MCF rubber and the glass. Liquid 1 was electrolyte $\mathrm{KI}+\mathrm{I}_{2}$ (potassium iodide $(\mathrm{KI})$ and iodine $\left(\mathrm{I}_{2}\right)$, both from FUJIFILM Wako Pure) containing $3.3 \mathrm{~g} \mathrm{I}_{2}$ in a solution of $40 \mathrm{~g} \mathrm{KI}$ and $60 \mathrm{~g}$ water; Liquid 2 was a liquid dye based on ruthenium complexes PEC-TOM-P04 (Peccell Technologies, Inc., Yokohama, Japan). The transparent glass illuminated by the ultraviolet light was coated with $\mathrm{TiO}_{2}$. Whether or not emulsifier PVA and water-insoluble rubber were used, the photovoltaic effect of emulsifier PVA and water-insoluble rubber Q appears in the same way as the photovoltaic effect of water-soluble rubber [6].

Regarding the data shown in Figure 2, the ruthenium complexes dye and electrolyte $\mathrm{KI}+\mathrm{I}_{2}$ are poured on the MCF rubber, which does not prevent their volatilization from the MCF rubber. Permeation of these liquids is needed in wet-type solar cells such as dye-sensitized solar cells. The fact that MCF rubber is permeable, as stated in (3) above, is thus of critical importance. Furthermore, we can make more permeation of some liquids. Whether the MCF rubber is 


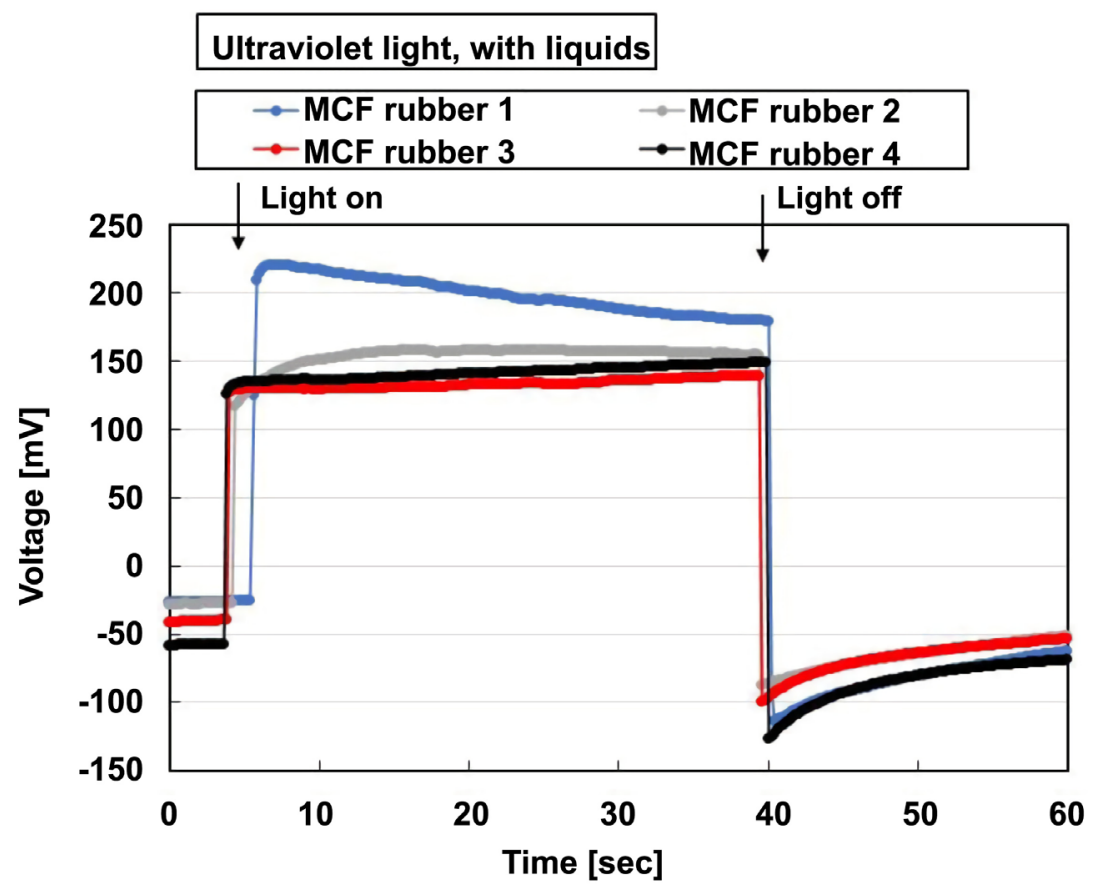

(a)

Ultraviolet light, without liquids

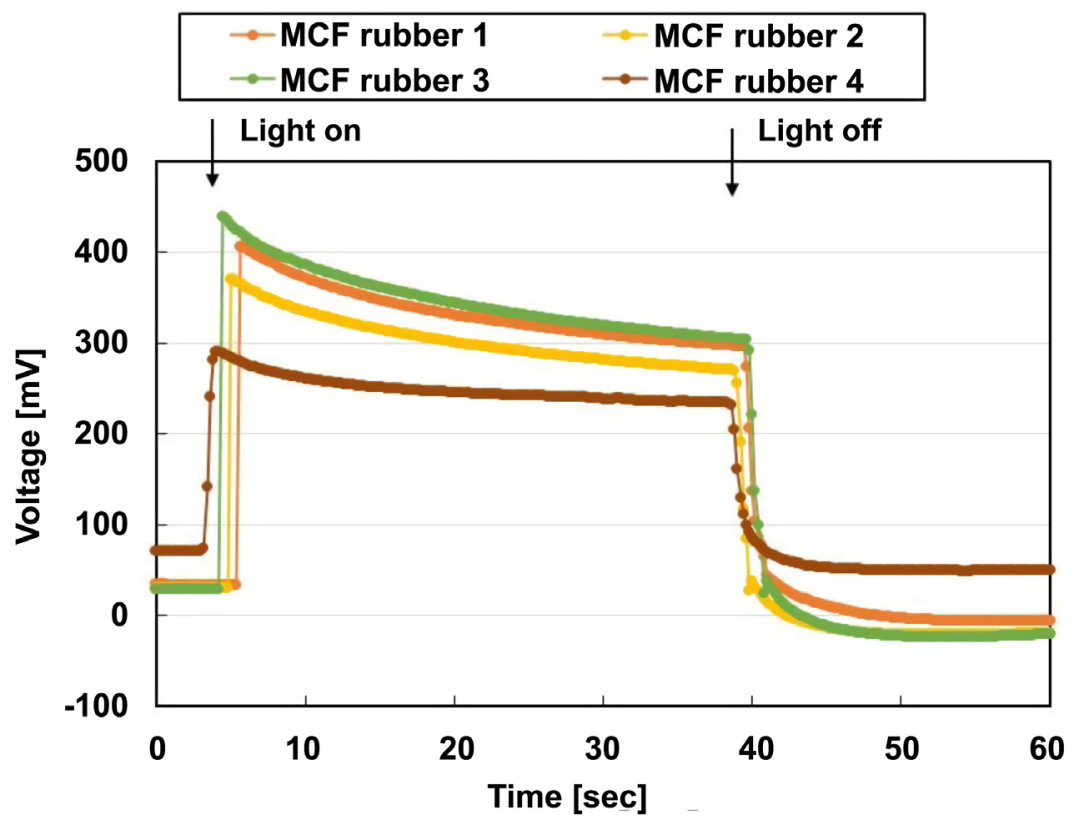

(b)

Figure 2. Changes in voltage by turning an ultraviolet light on and off (arrows) in the configuration shown in Figure 1: (a) liquids 1 and 2 were poured; (b) liquids 1 and 2 were not poured. For samples designated "with liquids," electrolyte $\mathrm{KI}+\mathrm{I}_{2}$ (Liquid 1) and ruthenium complexes dye (Liquid 2) were poured as shown in Figure 1.

made of water-soluble rubber or a combination of water-soluble and water-insoluble rubbers, by combining it with either metal complex hydrate 
$\mathrm{Na}_{2} \mathrm{WO}_{4} \cdot 2 \mathrm{H}_{2} \mathrm{O}$ or water, or by combining it with a mixture of the two, the MCF rubber becomes highly porous (see Figure A3 in Appendix) [20]. In the present study, we investigated the photovoltaic effects of porous MCF rubber (Figure 3). The MCF rubber was composed of 3 g KF96 (1000 cSt) + 3 g S-500 + 3 g 671 A + $3 \mathrm{~g}$ PVA $+0.75 \mathrm{~g} \mathrm{MF}(\mathrm{W}-40)+0.5 \mathrm{~g} \mathrm{TiO}_{2}+3 \mathrm{~g} \mathrm{Ni}+3 \mathrm{~g} \mathrm{Na}_{2} \mathrm{WO}_{4} \cdot 2 \mathrm{H}_{2} \mathrm{O}+3 \mathrm{~g}$ water.

Since $\mathrm{Na}_{2} \mathrm{WO}_{4} \cdot 2 \mathrm{H}_{2} \mathrm{O}$ can be used for adhesive MCF rubber liquid, which can serve as an adhesive glue, it was used in our experiment investigating the photovoltaic effects of adhesive MCF rubber liquid. The liquid which is combined with $\mathrm{Na}_{2} \mathrm{WO}_{4} \cdot 2 \mathrm{H}_{2} \mathrm{O}$ was electrolytically polymerized by applying a magnetic field of $312 \mathrm{mT}$ for $5 \mathrm{~min}$, and an electrode gap of $1 \mathrm{~mm}, 30 \mathrm{~V}$, and $2.7 \mathrm{~A}$. The transparent glass illuminated by ultraviolet light was coated with $\mathrm{TiO}_{2}$. While the experiment shown in Figure 2 measured changes in voltage with ultraviolet light, in order to investigate the behavior of the MCF rubber by deducing the capacitance related to charging and discharging by illumination, we conducted cyclic voltammetry of MCF rubber (Figure 4). We delivered 700-Lux ultraviolet light illumination to MCF rubber sandwiched between sheets of conductive transparent glass as shown in Figure 3, and the cyclic voltammograms were measured from electric wires 1 as a cathode and 2 as an anode by using a potentiostat (HA-151B; Hokuto Denko Co., Ltd., Tokyo, Japan) at a scan rate of 50 $\mathrm{mHz}$ in the potential domain of $-1.5-1.5 \mathrm{~V}$. As in the case of any liquid, charging by illumination was greater than discharging. On the voltammograms, the area of the hysteresis curve involving $\mathrm{TiO}_{2}$ and water was the largest of all hysteresis curve areas. This is due to enhancement because of the semiconductor-like role of $\mathrm{H}^{+}, \mathrm{OH}^{-}$and $\mathrm{TiO}_{2}$, which are induced by the photocatalysis of $\mathrm{TiO}_{2}$ [21]

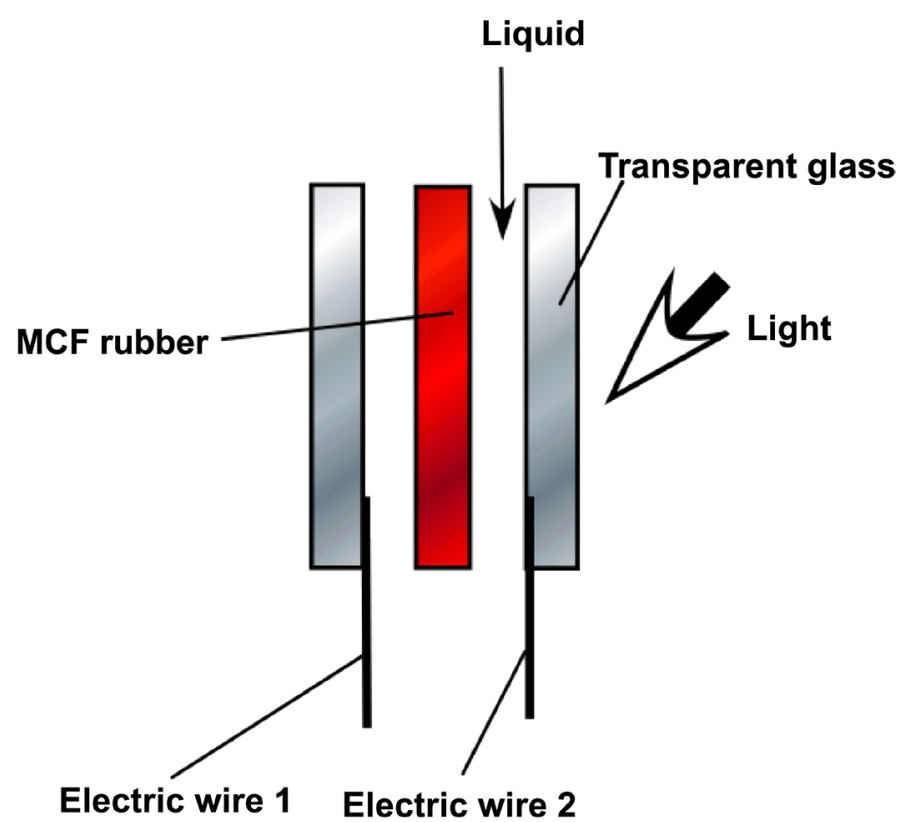

Figure 3. Experimental set-up to examine photovoltaic effects. 


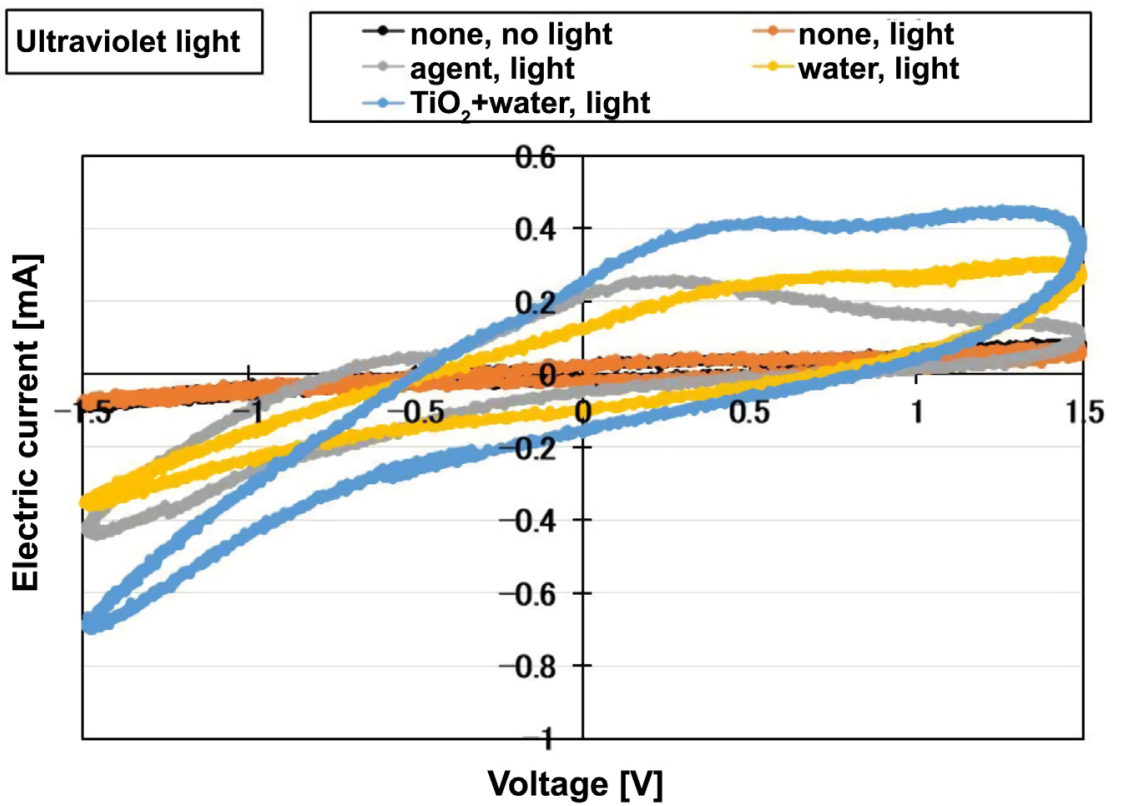

(a)

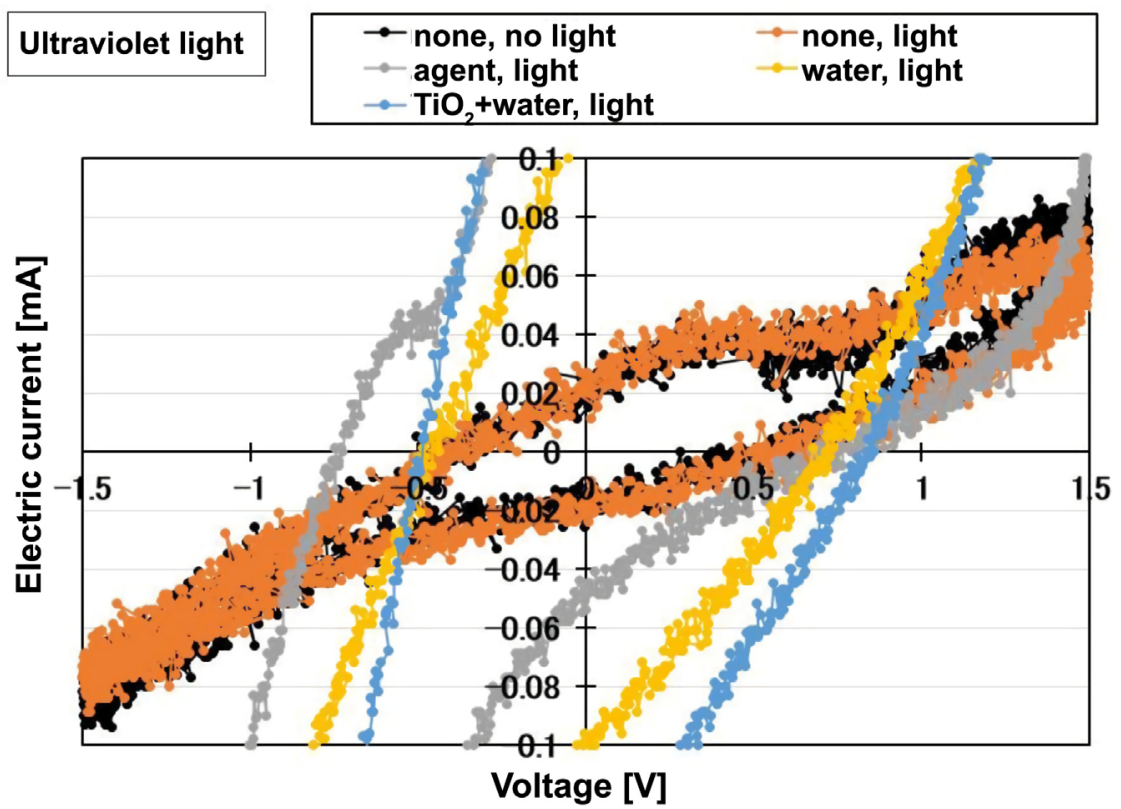

(b)

Figure 4. Cyclic voltammetry plots measured by potentiostat upon turning on an ultraviolet light: none, no liquid was used; agent, the poured liquid was ruthenium complexes dye; water, the poured liquid was water; $\mathrm{TiO}_{2}+$ water, the poured liquid consisted of $\mathrm{TiO}_{2}$ and water at a ratio of 1:10; light, illumination by ultraviolet light; no light, no illumination by ultraviolet light: (b) is magnifying of (a).

and the Honda-Fujishima effect [22]. $\mathrm{TiO}_{2}$ particles could have a photovoltaic effect since the combination of water and $\mathrm{TiO}_{2}$ has been reported to have such an effect with electrochemical photolysis; this is known as the Honda-Fujishima effect. The present hysteresis curve results may also be due to the enhancement 
of PVA conductivity by involving $\mathrm{Ni}$ [23]. These results clarify the photovoltaic effects of porous MCF rubber permeated with liquids and of adhesive MCF rubber liquids.

Next, by using the adhesive MCF rubber liquid with $\mathrm{Na}_{2} \mathrm{WO}_{4} \cdot 2 \mathrm{H}_{2} \mathrm{O}$, we can adhere the MCF rubber to the transparent glass coated with $\mathrm{TiO}_{2}$ using our proposed adhesion technique [18], which is part of our novel technique for the production of solar cells. The final structure has multiple layers, which is produced by the process: a single MCF rubber 1 was electrolytically polymerized in advance, and then again after it is placed between sheets of transparent glass and adhesive MCF rubber 2 is poured on the MCF rubber 1 . In contrast, in the present study, we developed the following procedure: single MCF rubber 1 and single adhesive MCF rubber 2 were electrolytically polymerized in advance (magnetic field, $312 \mathrm{mT}$; electrode gap, $1 \mathrm{~mm} ; 30 \mathrm{~V} ; 2.7 \mathrm{~A} ; 5 \mathrm{~min}$ ), and then they are sandwiched between sheets of transparent glass so that double layers of MCF rubber were produced (Figure 5). The cause is due to that adhesive MCF rubber liquid is eventually solidified by the electrolytic polymerization. MCF rubber liquid 2 corresponds to the adhesive MCF rubber liquid. The MCF rubber liquids are shown in Table 2. We poured the liquids between the surface of MCF rubber 2 and the transparent glass. The glass was coated with $\mathrm{TiO}_{2}$ and illuminated by ultraviolet light.

Illumination of 700-Lux ultraviolet light was delivered to the MCF rubber sandwiched between sheets of conductive transparent glass as shown in Figure 6 , and cyclic voltammograms were measured from electric wires 1 and 2 using a potentiostat at a scan rate of $50 \mathrm{mHz}$ in the potential domain of $-1.5-1.5 \mathrm{~V}$. We obtained the same results as those obtained in the previous experiment (Figure 4): as in the case of any liquid, charging by illumination was greater than discharging; and the area of the hysteresis voltammogram curve involving $\mathrm{TiO}_{2}$ and water was the largest of all hysteresis curve areas. Our results verify the effectiveness of the proposed production procedure in which MCF rubber electrolytically polymerized in advance is attached to $\mathrm{TiO}_{2}$-coated transparent glass and again electrolytically polymerized.

\subsection{Consummate Fabrication Process}

By using the three basic configurations (1)-(3) described above, MCF rubber solar cells can be produced by the consummate fabrication process diagrammed in Figure 7, which produces the fabricated structure shown in Figure 8. The constituents of the MCF rubber liquids used in this process are shown in Table 3.

Table 2. Constituents of the MCF rubber in Figure 5.

\begin{tabular}{cl}
\hline & \multicolumn{1}{c}{ Constitution } \\
\hline MCF rubber 1 & KF96: 3 g; S-500: 3 g; 671A: 3 g; PVA: 3 g; MF: 0.75 g; $\mathrm{TiO}_{2}: 0.5 \mathrm{~g}$ \\
MCF rubber 2 & $\begin{array}{l}\text { KF96: } 3 \text { g; S-500: } 3 \text { g; 671A: } 3 \text { g; PVA: } 3 \text { g; MF: } 0.75 \text { g; } \mathrm{TiO}_{2}: 0.5 \mathrm{~g} ; \\
\mathrm{Na}_{2} \mathrm{WO}_{4} \cdot 2 \mathrm{H}_{2} \mathrm{O}: 0.5 \mathrm{~g} \text {; water: } 3 \mathrm{~g}\end{array}$ \\
\hline
\end{tabular}




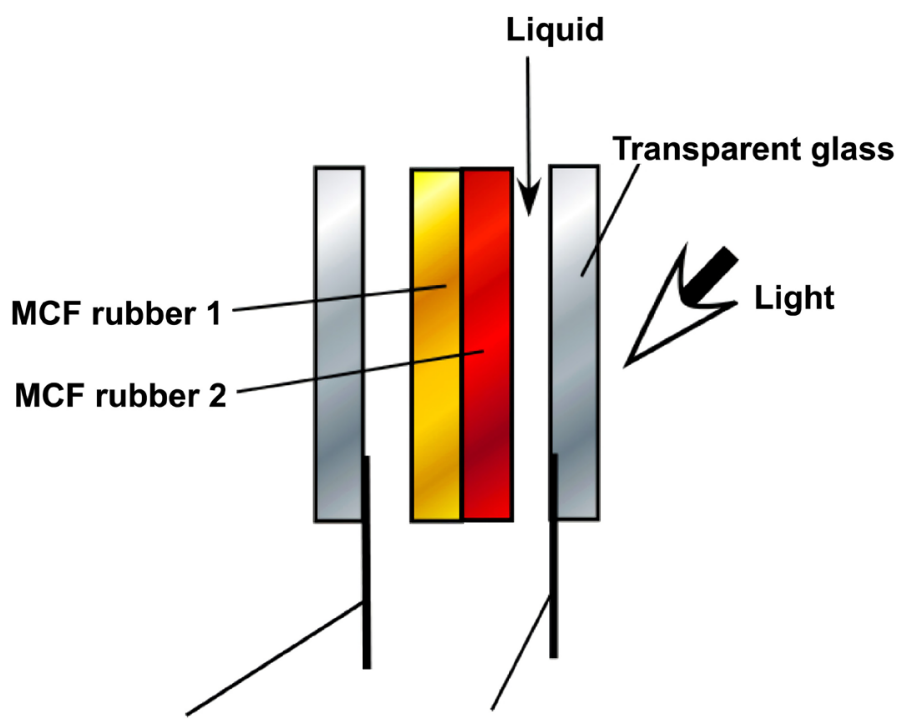

Electric wire $1 \quad$ Electric wire 2

Figure 5. Production of double-layered MCF rubber.

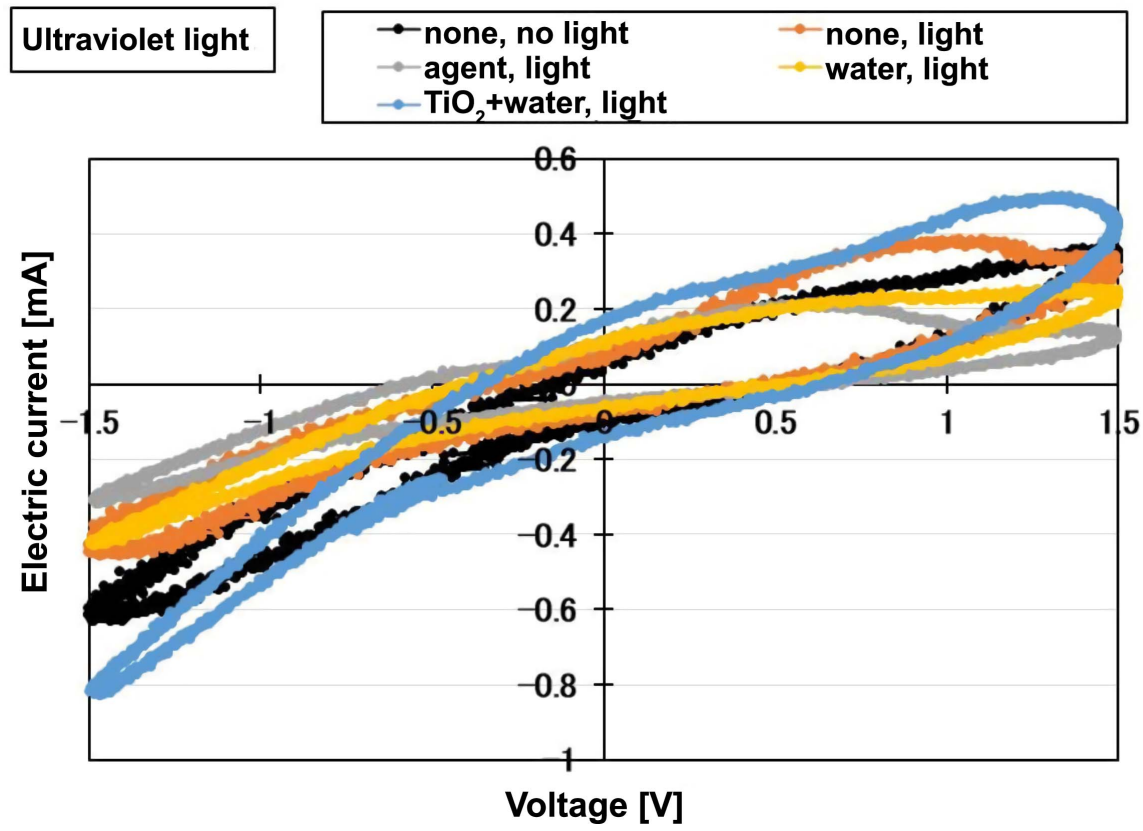

Figure 6. Cyclic voltammetry plots measured by potentiostat upon turning on an ultraviolet light using the set-up show in Figure 5: none, no liquid was used; agent, the poured liquid was ruthenium complexes dye; water, the poured liquid was water; $\mathrm{TiO}_{2}+$ water, the poured liquid consisted of $\mathrm{TiO}_{2}$ and water at a ratio of 1:10; light, illumination by ultraviolet light; no light, no illumination by ultraviolet light.

Table 3. Constituents of the MCF rubbers used in the consummate fabrication process.

\begin{tabular}{cl}
\hline & \multicolumn{2}{c}{ Constitution } \\
\hline MCF rubbers 1-1, 1-2, 3 & KF96: 3 g; S-500: 3 g; 671A: 3 g; PVA: 3 g; MF: 0.75 g; TiO $: 0.5$ g \\
MCF rubber 2 & KF96: 3 g; S500: 3 g; 671A: 3 g; PVA: 3 g; MF: 0.75 g; TiO $: 0.5$ g; \\
& Na $_{2} \mathrm{WO}_{4} \cdot 2 \mathrm{H}_{2} \mathrm{O}: 0.5 \mathrm{~g}$
\end{tabular}



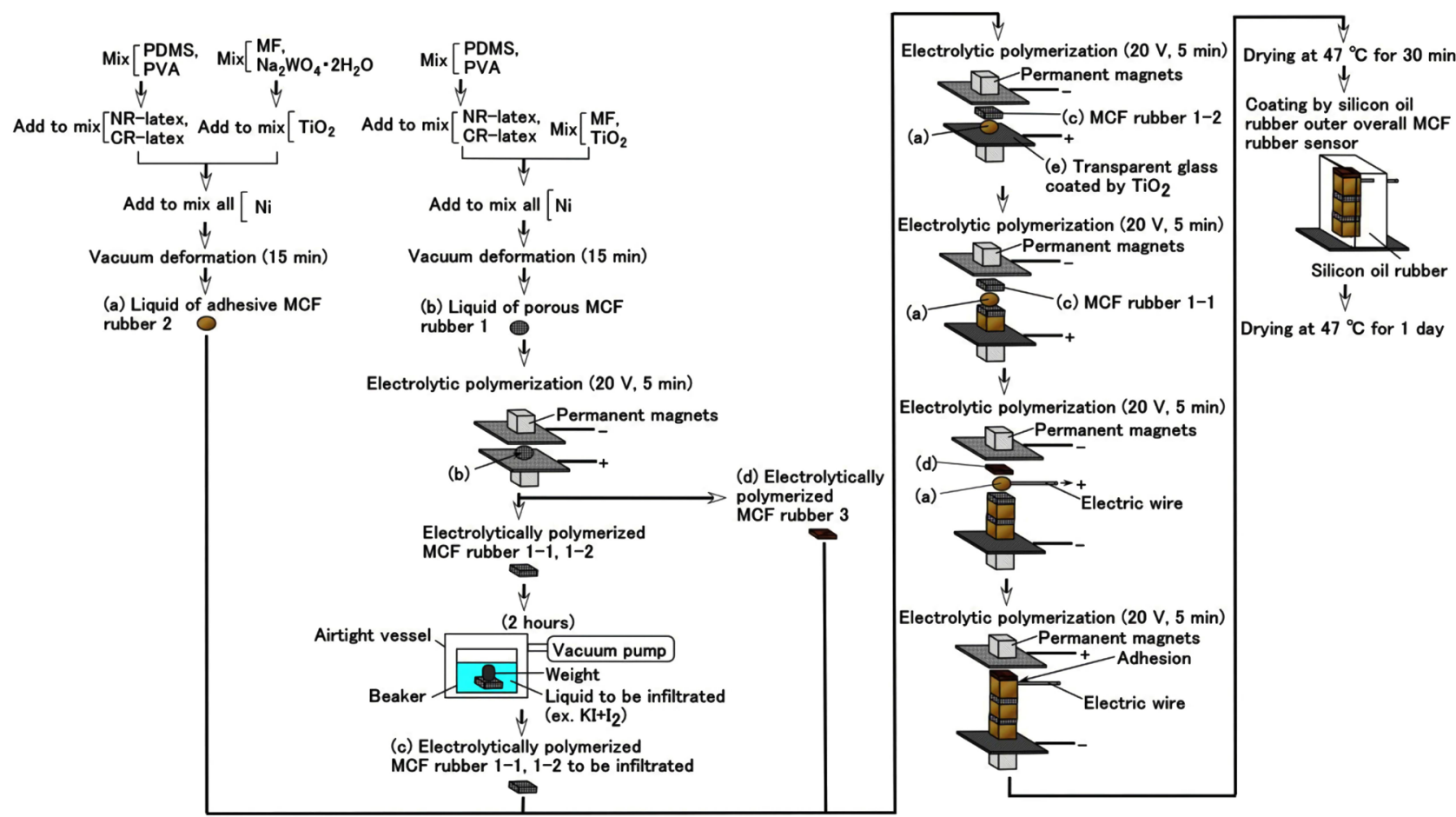

Figure 7. Consummate fabrication procedure of MCF rubber sensors.

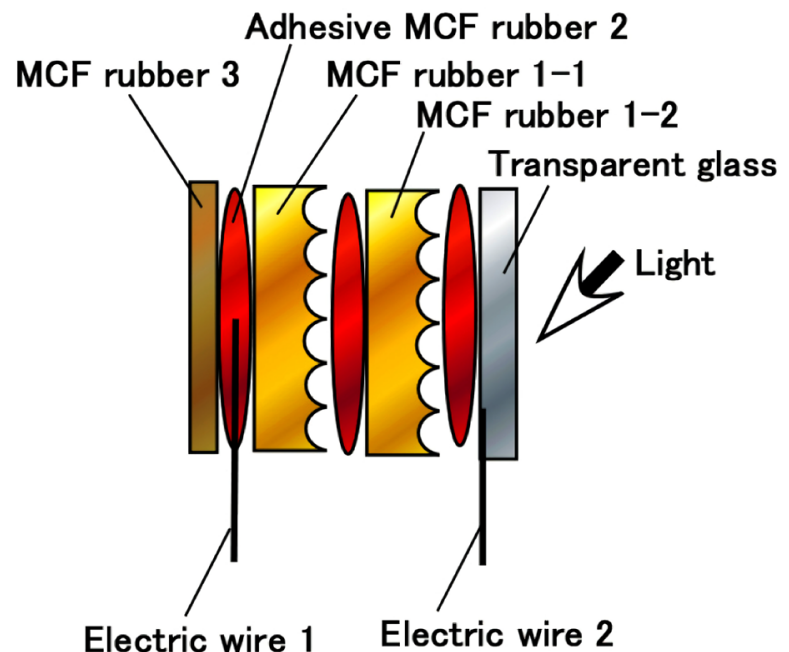

Figure 8. Structure of the MCF rubber solar cells produced by consummate fabrication.

Because MCF rubber liquid 2 must be adhesive, it involves $\mathrm{Na}_{2} \mathrm{WO}_{4} \cdot 2 \mathrm{H}_{2} \mathrm{O}$. Electrolytically polymerized MCF rubbers 1-1 and 1-2 are porous and are infiltrated by liquids by evacuation. The percolating fluids were a $\mathrm{KI}+\mathrm{I}_{2}$ solution as electrolytes and a liquid dye based on ruthenium complexes PEC-TOM-P04. We compared the rubbers infiltrated by liquids (1-1 and 1-2) to those not infiltrated by liquids (2 and 3). Although MCF rubber 3 has the same constitution as MCF rubbers 1-1 and 1-2, it was used to cover the solar cells. One electrode of the solar cells is $\mathrm{TiO}_{2}$-coated transparent glass and the other is electric wire 1 , which is 
sandwiched between MCF rubbers 3 and 1-1. If the transparent glass is made of a flexible material such as Q rubber in the future, rubber-type solar cells will be sufficiently elastic and extensible to broaden artificial skins installed with solar cells and sensors. We can also utilize the commercial transparent conductive polymer sheet and then the polymer sheet is flexible and practical enough to be used for the current flexible solar cell. Our results obtained in the present study will contribute to our understanding of their characteristics in future research. Since the purpose of the present study is to elucidate the viability of our proposing MCF rubber sensor to the photovoltaic and irradiation fields, we use transparent glass in the present study and will deal with the development of transparent conductive material such as glass in other studies. Electric wire 2 was attached to the surface of the glass.

The surfaces of MCF rubbers 1-1 and 1-2, which are convex-concave, settled into this shape during the electrolytic polymerization with adhesive MCF rubber liquid 2 (Figure 8; see also Figure 1). Electrolytic polymerization was carried out with a magnetic field of $312 \mathrm{mT}$ and an electrode gap of $1 \mathrm{~mm}$. Finally, the fabricated MCF rubber solar cells were coated with silicone oil rubber (KE1300T + curing agent) to protect it from extraneous damage. Figure 9 shows the completed MCF rubber solar cells. Due to the application of a magnetic field, the magnetic clusters are fabricated by $\mathrm{Fe}_{3} \mathrm{O}_{4}$ and $\mathrm{Ni}$, yielding a bulk heterostructure inside the MCF rubber by containing many thin-rod-shaped magnetic clusters. It is said that this type of configuration is sufficiently effective in solar cells to enhance their photovoltaic effect. Although this configuration is difficult to structure, our proposed consummate fabrication process makes it possible to create the ideal structure easily. Figure 10 shows changes in the photovoltaic voltage with illumination by 700 -Lux ultraviolet light, with and without percolating the electrolyte solution and dye. The photovoltage with percolation was larger than that without percolation. However, the photovoltaic effect exists even without percolation. This result is the same as that in our previous study [6] and has the same cause: the built-in electricity occurs due to ionized molecules and particles of the rubber latex, oleic acid coated around $\mathrm{Fe}_{3} \mathrm{O}_{4}$ of $\mathrm{MF}$, and water, all of which together play the roles of an acceptor-like p-type semiconductor (corresponding to $\mathrm{A}^{-}$) and of donor-like $\mathrm{n}$-type semiconductor (corresponding to $\left.\mathrm{D}^{+}\right)$.

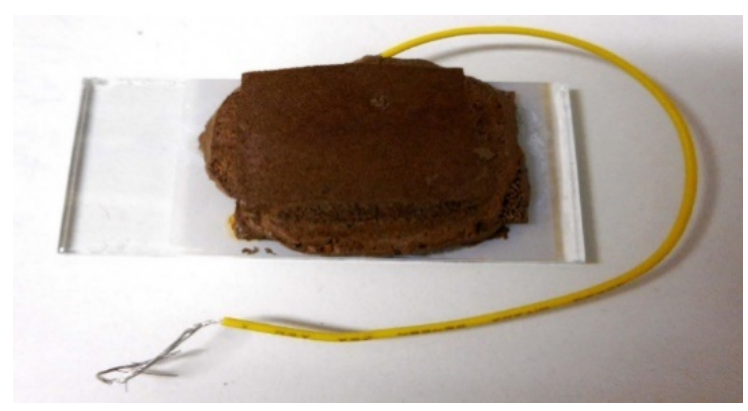

Figure 9. Image of MCF rubber solar cells produced by consummate fabrication. 


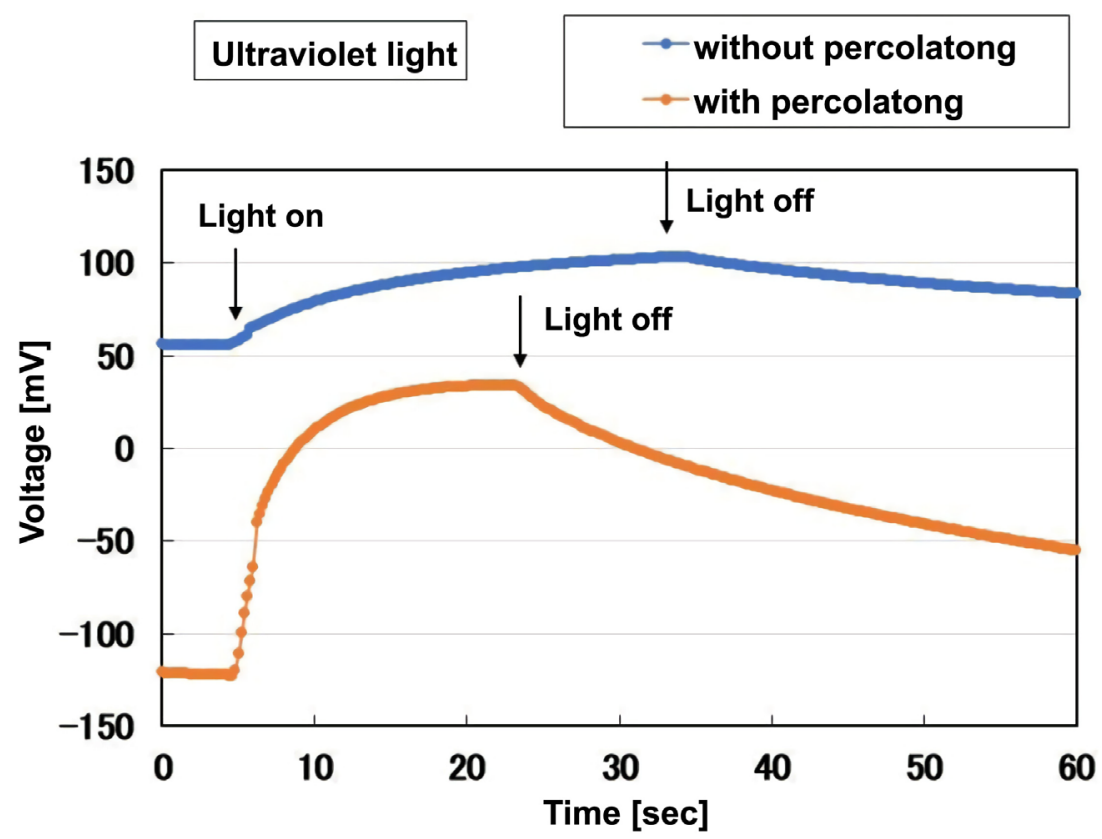

Figure 10. Changes in the voltage of MCF rubber solar cells produced by consummate fabrication when turning an ultraviolet light on and off (arrows): with percolation, ruthenium complexes dye and $\mathrm{KI}+\mathrm{I}_{2}$ electrolyte solution were percolated; without percolation, no percolation of either the dye or the electrolyte solution was performed.

\section{3. $\gamma$-Ray Irradiation}

We investigated the $\gamma$-irradiation effect of the MCF rubber solar cells produced by our proposed consummate fabrication process at the irradiation facility at the Laboratory for Advanced Nuclear Energy of the Tokyo Institute of Technology (Tokyo, Japan) using the set-up shown in Figure 11.

The $\gamma$-rays were irradiated from a ${ }^{60} \mathrm{Co}$ source and the absorbed dose rate was $230 \mathrm{~Gy} / \mathrm{h}$. The voltage and electric current of the MCF rubber solar cells induced by the irradiation were measured both with and without 900-Lux ultraviolet illumination. The ultraviolet light was delivered to the MCF rubber solar cells by flare. The voltage $V$ and electric current $I$ induced by $\gamma$-irradiation and ultraviolet light illumination are shown in Figure 12. Without irradiation, the flare could be turned on and off in the $\gamma$-irradiation chamber by a human being, but this is not possible with irradiation. Measurement therefore began after the flare was turned on. Without $\gamma$-irradiation, the induced voltage and current increase due to ultraviolet light illumination ("a" in Figure 12), while with $\gamma$-irradiation, they decrease with ultraviolet light illumination (" $b$ " in Figure 12). Without ultraviolet light illumination, the voltage and current induced by $\gamma$-irradiation decrease ("c" in Figure 12), while with ultraviolet light illumination, they decrease (“d” in Figure 12).

Cyclic voltammograms of the MCF rubber solar cells in the $\gamma$-irradiation facility were measured using a potentiostat at a scan rate of $50 \mathrm{mHz}$ in the potential domain of $-1.5-1.5 \mathrm{~V}$ (Figure 13). Whether or not $\gamma$-rays are irradiated, the 


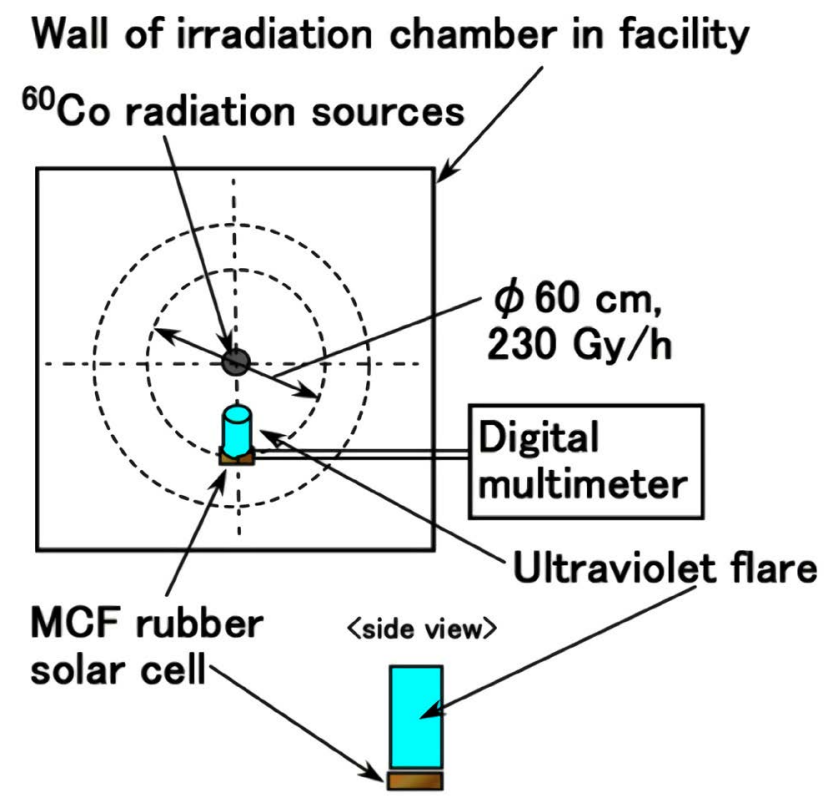

Figure 11. Schematic diagram of the set-up used to test $\gamma$-irradiation at the facility.

area of the hysteresis voltammogram curve increases due to ultraviolet light illumination. However, whether or not ultraviolet light is irradiated, the area of the hysteresis voltammogram curve decreases due to $\gamma$-irradiation.

We examined our obtained results in the light of existing knowledge about MSs, MISs and MOSs as follows.

As with the well-known consequence that $\gamma$-irradiation generates e-h pairs in the interfacial insulator of solar cells and semiconductors [23], e-h pairs are generated by $\gamma$-rays in the interfacial insulator of PDMS, NR molecules, oleic acid and PVA in MCF rubber solar cells. Simultaneously, $\mathrm{A}^{-}$corresponding to the role of acceptor-like p-type semiconductors and $\mathrm{D}^{+}$corresponding to the role of donor-like n-type semiconductors are generated from the molecules of $\mathrm{TiO}_{2}, \mathrm{Fe}_{3} \mathrm{O}_{4}, \mathrm{Ni}, \mathrm{Na}_{2} \mathrm{WO}_{4} \cdot 2 \mathrm{H}_{2} \mathrm{O}$, PDMS, NR, oleic acid, PVA and water, and the depletion layer is enhanced. The mechanism is induced by the following process.

$\gamma$-irradiation emits electrons, $\mathrm{e}_{\mathrm{aq}}$, which are generated as shown in Equation (1) and then bring about a radiation-chemical reaction by attacking metal, $M$, as shown in Equation (2) [24]. In addition, at the level of composite iron oxide nanoparticles, metal forms on iron oxide, as shown in Equation (3), and noble metals form in the aqueous phase and are then immobilized on iron oxide, as shown in Equation (4) [25].

$$
\begin{gathered}
\mathrm{H}_{2} \mathrm{O} \stackrel{\gamma \text {-irradiation }}{\longrightarrow} \mathrm{e}_{\mathrm{aq}}, \mathrm{H}_{3} \mathrm{O}^{+}, \mathrm{OH}^{-} \\
\mathrm{e}_{\mathrm{aq}}+\mathrm{M}^{n+} \rightarrow \mathrm{M}^{(n-1)+} \\
\mathrm{M}^{n+} \text { (on oxide) } \rightarrow \mathrm{M}^{0} \text { (on oxide) } \\
\left.\mathrm{M}^{n+} \text { (aq.) } \rightarrow \mathrm{M}^{0} \text { (aq.) }\right) \rightarrow \mathrm{M}^{0} \text { (on oxide) }
\end{gathered}
$$

$\mathrm{TiO}_{2}$ in the form of the $\mathrm{M}^{n+}, \mathrm{TiO}_{4}^{+}$, makes the polyisoprene molecules of $\mathrm{NR}$ 


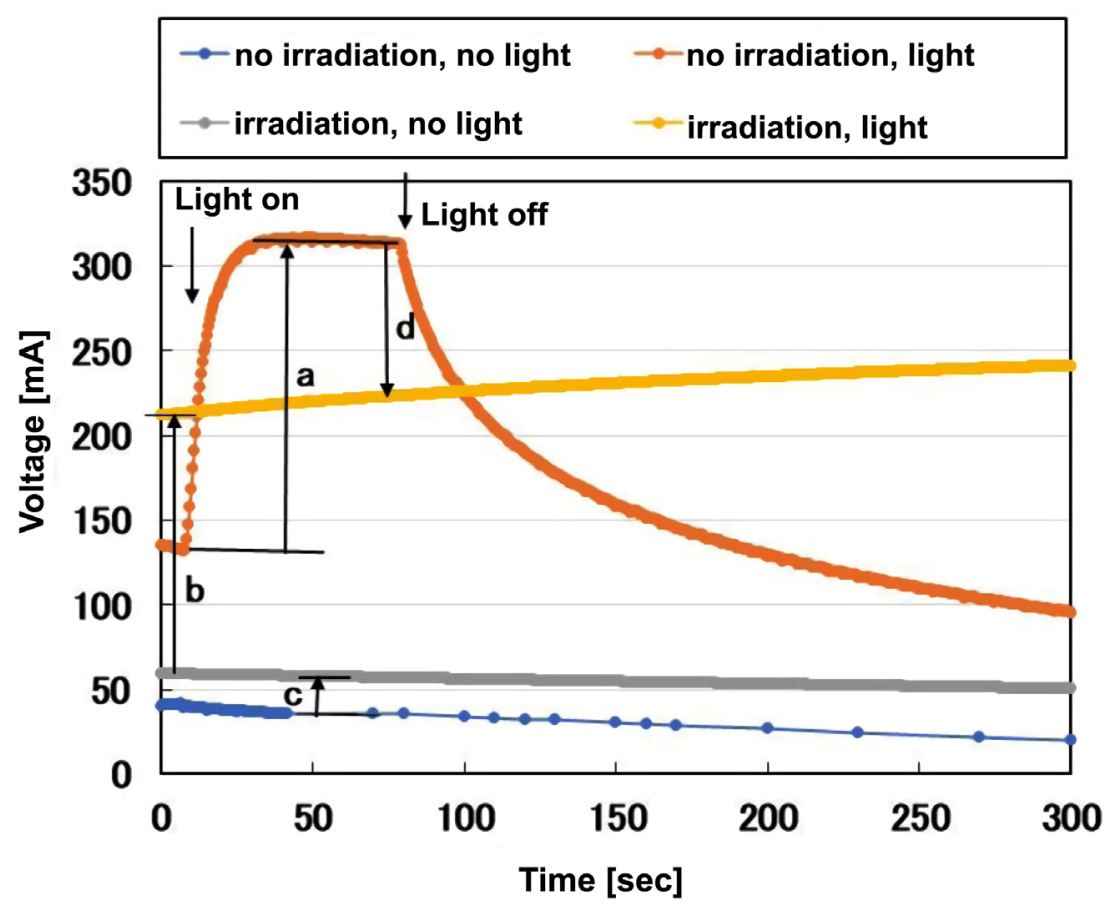

(a)

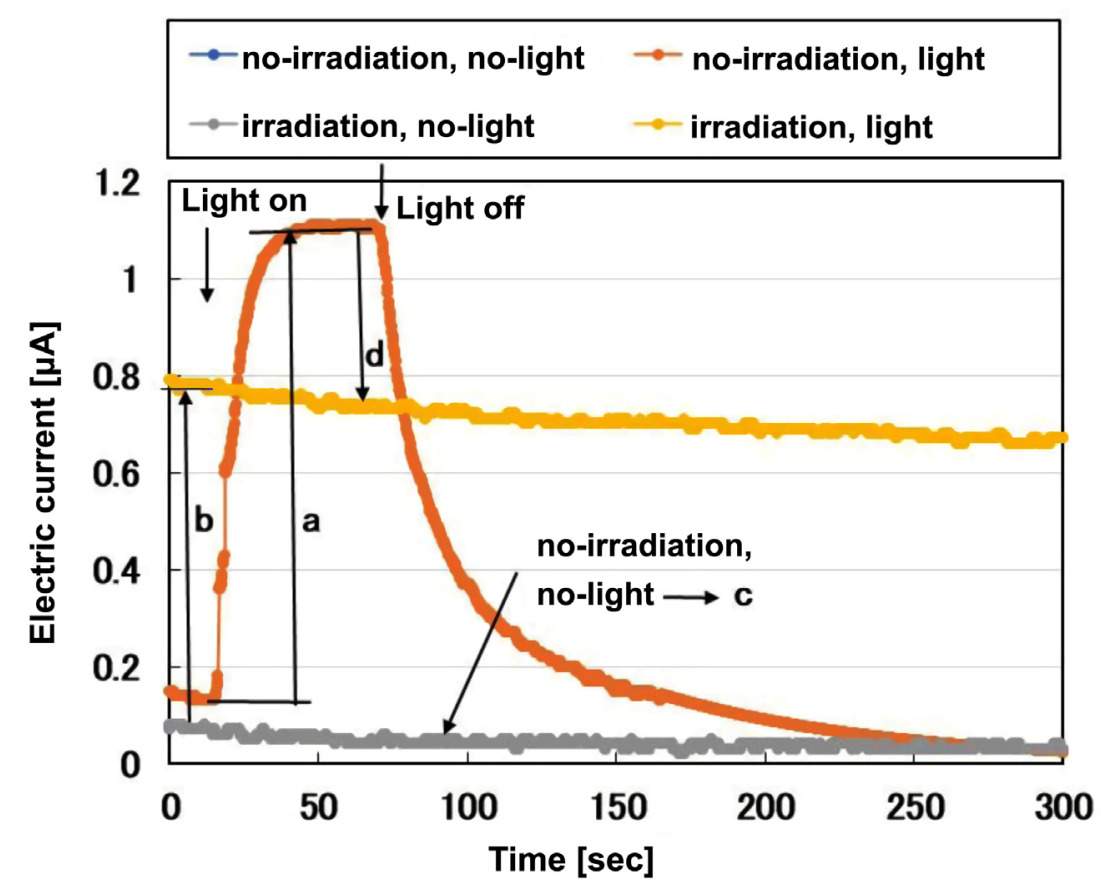

(b)

Figure 12. Voltage and electric current of the MCF rubber solar cells induced by $\gamma$-irradiation and ultraviolet light illumination: (a) voltage; (b) electric current: irradiation, with irradiation by $\gamma$-rays; no irradiation, without irradiation by $\gamma$-rays; light, with illumination by ultraviolet light; no light, without illumination by ultraviolet light. The ultraviolet light was turned on and off at the times indicated by the arrows. Note that the "no-irradiation, no-light" condition shows almost the same quantitative magnitude as the "irradiation, no-light" condition in (b), and "c" is very small. 


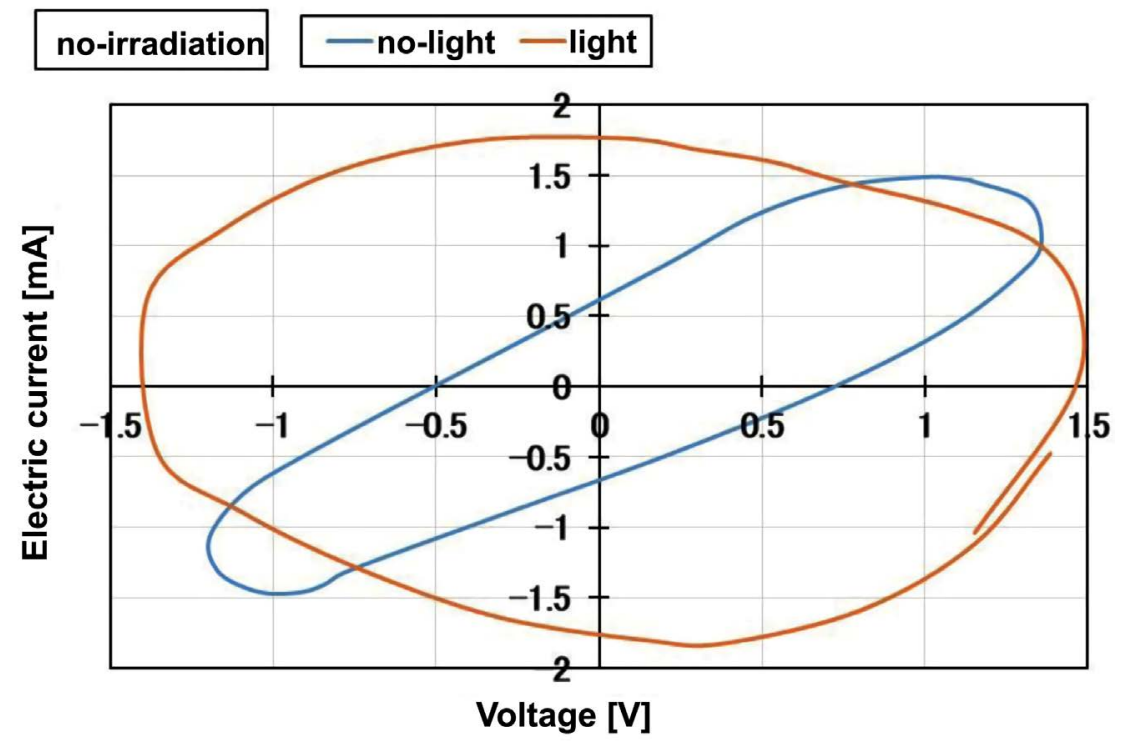

(a)

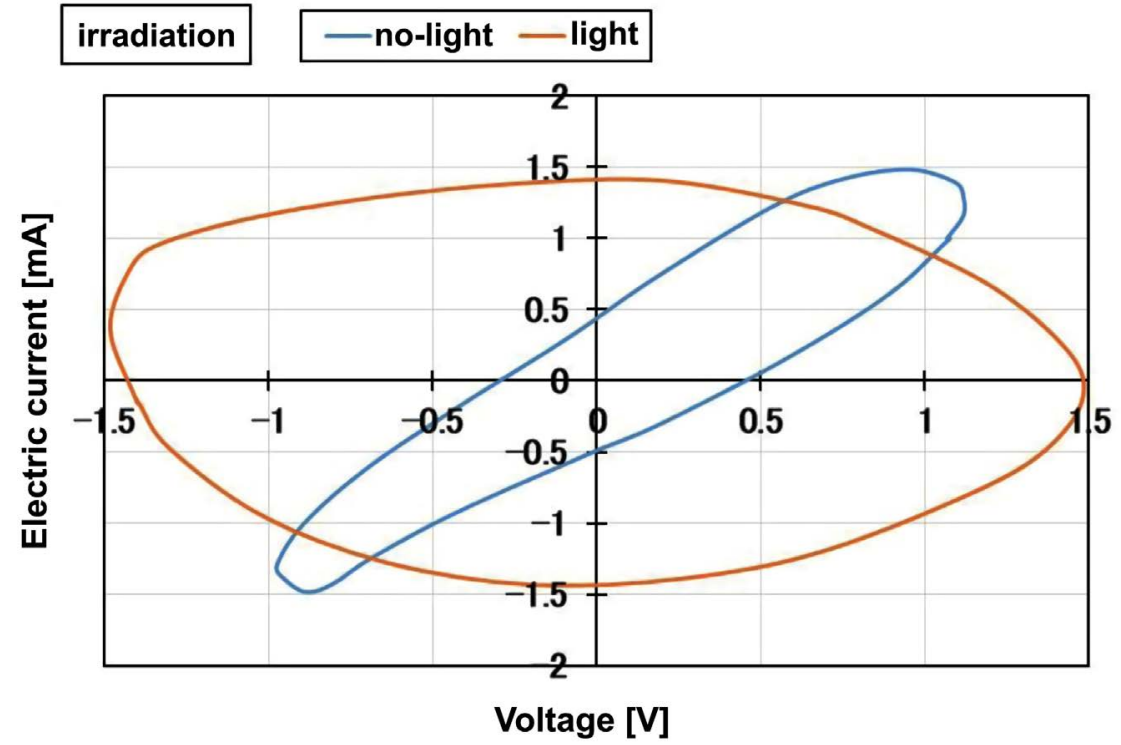

(b)

Figure 13. Cyclic voltammetry plots of the MCF rubber solar cells under $\gamma$-irradiation and ultraviolet light illumination: (a) without $\gamma$-irradiation; (b) with $\gamma$-irradiation: light, with illumination by ultraviolet light; no light, without illumination by ultraviolet light.

radical, as shown in Equation (5) [7], which means that it functions as a catalyst, with the result that the radical polyisoprene molecules become oxidants.

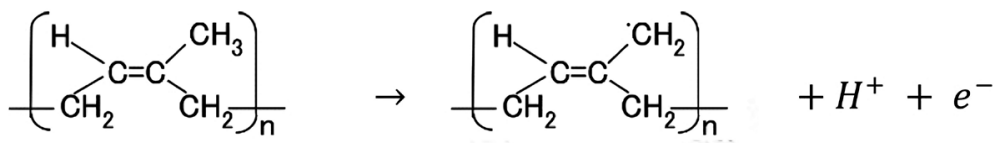

Concerning the reverse-bias saturation current $I_{\mathcal{S}}$ we can deduce as follows. The Schottky barrier generated between the energy potential of the $\mathrm{M}^{n+}$ of $\mathrm{TiO}_{2}$, $\mathrm{Fe}_{3} \mathrm{O}_{4}, \mathrm{Ni}$, and $\mathrm{Na}_{2} \mathrm{WO}_{4} \cdot 2 \mathrm{H}_{2} \mathrm{O}$, and that of the $\mathrm{H}^{+}$, radical polyisoprene, is increased by $\gamma$-irradiation. There is also the emission of electrons from $\mathrm{TiO}_{2}$ by 
$\gamma$-irradiation, identified in our previous study [1] because as the electron falls into the inner shell, it causes an avalanche of outer-shell electrons. As a result, the diffusion potential $V_{D}$ increases. The MCF rubber solar cells were analyzed by an equivalent electric circuit using Equation (6) [26], where $I$ is the electric current of solar cells, $I_{p h}$ is the photocurrent, $I_{d}$ is the diode current, $I_{s h}$ is the shunt current, $e$ is the elementary charge of electrons, $V$ is the voltage of solar cells, $R_{s}$ is the series resistance, $N$ is the diode ideality factor, $k$ is the Boltzmann constant, $T$ is the absolute temperature, and $R_{s h}$ is the shunt resistance.

$$
I=I_{p h}-I_{d}-I_{s h}=I_{p h}-I_{D}\left[\exp \left\{\frac{e\left(V+R_{s} I\right)}{N k T}\right\}-1\right]-\frac{V+R_{s} I}{R_{s h}}
$$

$I_{s}$ is shown in Equation (7) [10], where $A$ is the effective diode area and $A^{*}$ is the effective Richardson constant. Then, as $V_{D}$ increases, $I_{s}$ is enhanced. $I_{s}$ stems from the enhancement of current leakage between $\mathrm{A}^{-}$and $\mathrm{D}^{+}$in the MCF rubber.

$$
I_{s}=A A^{*} T^{2} \exp \left(-\frac{e V_{D}}{k T}\right)
$$

On the other hand, we can deduce the tendency of $N$ as follows. $N$ is equal to $V /\left(V_{f}-V_{i}\right)$, where $V_{f}$ is the forward-bias voltage and $V_{i}$ is the voltage drop at the thin isolated layer. Recognizing the consequences clarified in other studies on solar cells with $\gamma$-irradiation [10] [27], we investigated changes in $N$ that also arise as a result of the enhancement of current leakage between $\mathrm{A}^{-}$and $\mathrm{D}^{+}$in MCF rubber as follows. The method as presented in the study [10] is effective to evaluate $N$ from the relation between electric current and voltage obtained by cyclic voltammetry as shown in Figure 13.

By applying Equation (8), which is derived from Equation (6), with deriving from Figure 13, we can obtain $R_{s}$ as gradient of Equation (8) and $N k T / e$ as a constant of Equation (8) to the variable $I$, as shown in Table 4. "Decreasing vias voltage" and "Increasing bias voltage" mean decreasing and increasing voltage of Figure 13 respectively. Therefore, with respect to $R_{s}$ and $N k T / e$, "decreasing" and "increasing" are different because the capacity of discharge and the capacity of charge in the MCF rubber are different. Then the resistance among molecules of $\mathrm{TiO}_{2}, \mathrm{Fe}_{3} \mathrm{O}_{4}, \mathrm{Ni}, \mathrm{Na}_{2} \mathrm{WO}_{4} \cdot 2 \mathrm{H}_{2} \mathrm{O}, \mathrm{PDMS}$, NR, oleic acid, PVA and water changes diversely according to the ultraviolet light illumination and $\gamma$-irradiation conditions. Regarding $N k T / e$, the quantitative relation between $V_{i}$ and $V_{f}$ can be seen from $N k T / e$, as shown in Figure 14. The difference in the absolute value of the gradient of the linear line demonstrates the magnitude correlation between $V_{i}$ and $V_{f}$ In cases of ultraviolet light illumination, $\gamma$-irradiation, or synchronizing ultraviolet light illumination and $\gamma$-irradiation, $N$ increases. $V_{f}$ is increased by $\gamma$-irradiation regardless of ultraviolet light illumination. In the case of ultraviolet light illumination, $V_{f}$ is larger than $V_{i}$ regardless of $\gamma$-irradiation.

$$
\frac{\mathrm{d} V}{\mathrm{~d} \ln I}=R_{s} I+\frac{N k T}{e}
$$


Table 4. Analyzed coefficients of Equation (7): *, the electric current passing through Rs is a reverse electric current; decreasing, a decreasing application of voltage; increasing, an increasing application of voltage.

\begin{tabular}{|c|c|c|c|c|c|c|c|c|}
\hline \multirow{3}{*}{$\begin{array}{c}\begin{array}{c}\text { Ultraviolet light } \\
\text { illumination }\end{array} \\
\gamma \text {-irradiation }\end{array}$} & \multicolumn{4}{|c|}{$R_{s}$} & \multicolumn{4}{|c|}{$N k T / e$} \\
\hline & \multicolumn{2}{|c|}{ Off } & \multicolumn{2}{|c|}{ On } & \multicolumn{2}{|c|}{ Off } & \multicolumn{2}{|c|}{ On } \\
\hline & Off & On & Off & On & Off & On & Off & On \\
\hline Decreasing voltage & $-0.6836^{*}$ & $-11.245^{*}$ & 13.583 & $-2.7328^{\star}$ & 0.3585 & 0.587 & 13.966 & 1.0367 \\
\hline Increasing voltage & $-9.8453^{*}$ & $-2.528^{\star}$ & $-2.5667^{*}$ & 6.4454 & 0.0248 & 0.1047 & 0.5911 & 1.9939 \\
\hline
\end{tabular}

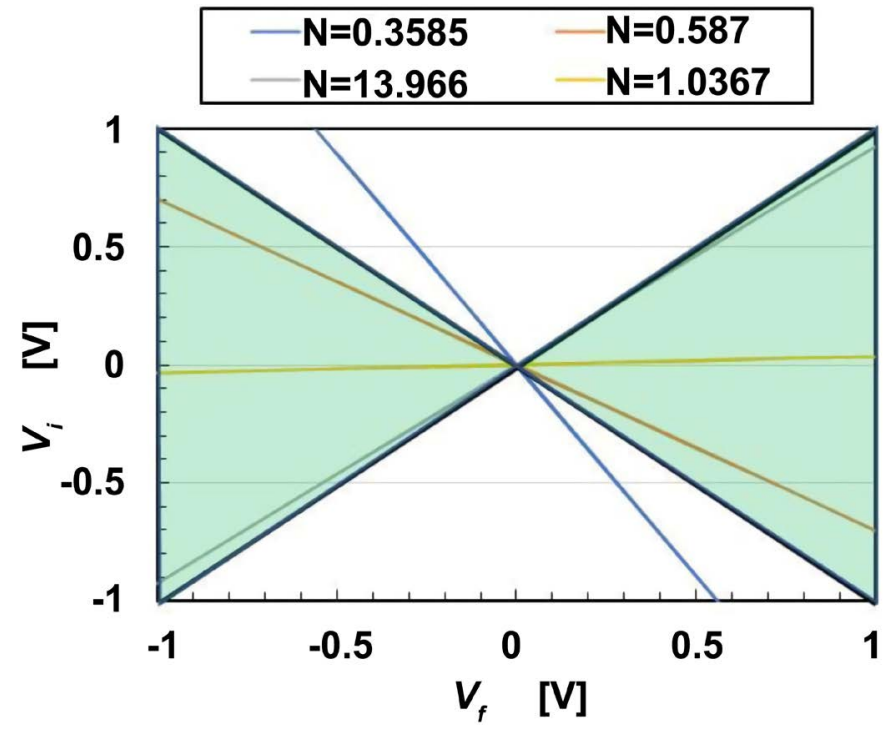

(a)

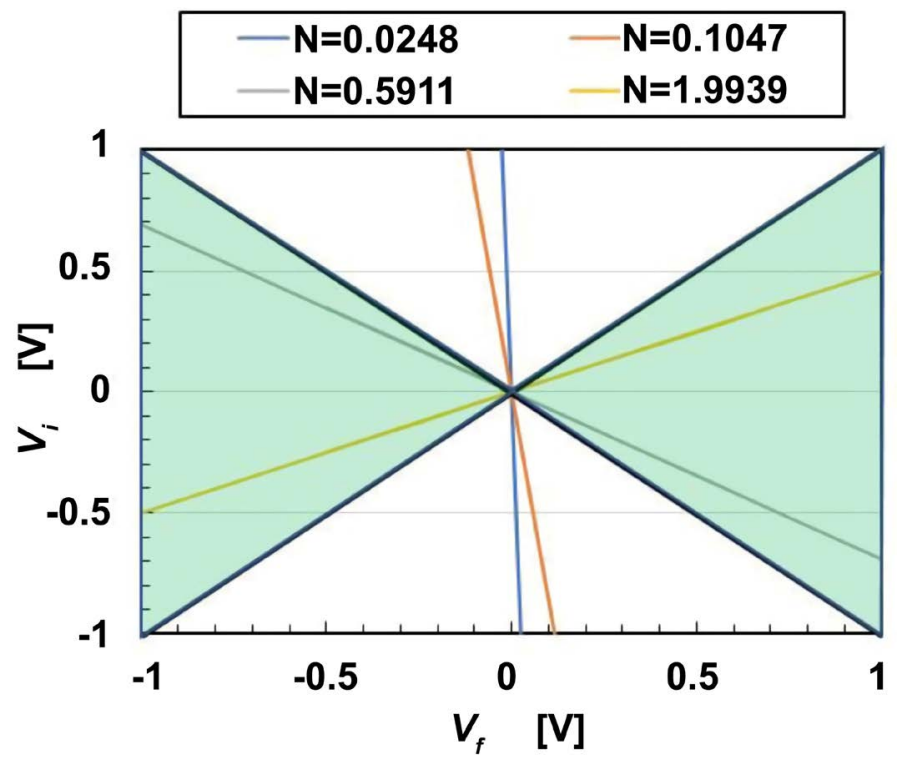

(b)

Figure 14. Relation between $V_{i}$ and $V_{f}$ from $N k T / e$ : (a) in the case of decreasing voltage; (b) in the case of increasing voltage. Areas marked in light green are areas in which $V_{f}$ is larger than $V_{i}$ 
Thus, as a result, $\gamma$-irradiation causes current leakage so that $I_{s}$ and $N$ increase. We can consider PDMS, NR, oleic acid and PVA as the insulator. When there exists very thin insulator on the surface of the semiconductor, Equation (6) is approximated to Equation (9). As a result, $I$ increases.

$$
I=I_{s} \exp \left(-\frac{e V_{f}}{N k T}\right)
$$

Regarding photocurrent, the conductivity of PVA increases by doping $\mathrm{Ni}$ in the PVA so that the photocurrent also increases by $\gamma$-irradiation, as discussed in the previous study [23]. The conductivity of $\mathrm{Fe}_{3} \mathrm{O}_{4}$ [28] and $\mathrm{TiO}_{2}$ [29] is also increased by $\gamma$-irradiation.

The above results together mean that these tendencies induce the enhancement of photovoltage and photocurrent by illumination, which is consistent not only with the trends indicated as "a" and "b" in Figure 12 but also with the enhancement of the area of the hysteresis voltammogram curve by ultraviolet light illumination shown in Figure 13.

In contrast, transmittance through the $\mathrm{TiO}_{2}$-coated transparent glass, which is caused by fluorine-doped tin oxide (FTO), decreases and the dye-sensitized solar cells is degraded by $\gamma$-rays, as demonstrated in the previous study [30].

In addition, it is important to also take into consideration that the effect of the attenuation of photon energy is larger than the effect of the creation of e-h pairs generated by $\gamma$-irradiation. In general, the photon energy of $\gamma$-rays attenuates through a material by the electron pair effect, the Compton effect, and the photoelectric effect, the first two of which are created at high photon energy, and the third of which is created at low photon energy. Because $\mathrm{Fe}_{3} \mathrm{O}_{4}, \mathrm{Na}_{2} \mathrm{WO}_{4} \cdot 2 \mathrm{H}_{2} \mathrm{O}$ and magnetic cluster are involved in MCF rubber solar cells, all of these effects are created to a greater or lesser extent, as seen from the following.

From Equation (3) and Equation (4), we see that $\mathrm{Fe}$ forms on $\mathrm{Fe}_{3} \mathrm{O}_{4}$. The attenuation of photon energy has been clarified by the collision of $\gamma$-rays with $\mathrm{Fe}$, $\mathrm{Pb}$ and $\mathrm{W}$ [31]. As a result, the photon energy is attenuated at $\mathrm{Fe}_{3} \mathrm{O}_{4}$.

Regarding $\mathrm{W}$, it has been clarified that the photon energy attenuates at the oxide of $\mathrm{W}$ particles as well as at $\mathrm{W}$ metal [32]. Therefore, the photon energy also attenuates due to $\mathrm{W}$ of $\mathrm{Na}_{2} \mathrm{WO}_{4} \cdot 2 \mathrm{H}_{2} \mathrm{O}$.

As for the electron pair effect, an electromagnetic field is needed. In the case of MCF rubber, magnetic cluster is magnetized and the magnetic field line is closed in the magnetic cluster so that an internal electromagnetic field exists [3]. Therefore, the electron pair effect could be created in MCF rubber solar cells and photon energy might also attenuate at the magnetic cluster.

As a result, the photovoltage and photocurrent under ultraviolet light illumination decrease by $\gamma$-irradiation, which demonstrates not only the trends indicated as " $c$ " and "d" in Figure 12 but also the decrease in the area of the hysteresis voltammogram curve by $\gamma$-irradiation in Figure 13 .

$I_{S}$ and $N$ resulting from the enhancement of the diffusion potential $V_{D}$ are in- 
creased not only by the e-h pairs generated by $\gamma$-rays in the interfacial insulator of PDMS, NR molecules, oleic acid and PVA in MCF rubber solar cells, but also by the p- and n-type semiconductor-like roles of the molecules of $\mathrm{TiO}_{2}, \mathrm{Fe}_{3} \mathrm{O}_{4}$, $\mathrm{Ni}, \mathrm{Na}_{2} \mathrm{WO}_{4} \cdot 2 \mathrm{H}_{2} \mathrm{O}, \mathrm{PDMS}, \mathrm{NR}$, oleic acid, PVA and water. Additionally, the photon energy of $\gamma$-irradiation attenuates owing to the $\mathrm{Fe}_{3} \mathrm{O}_{4}, \mathrm{Na}_{2} \mathrm{WO}_{4} \cdot 2 \mathrm{H}_{2} \mathrm{O}$ and magnetic cluster involved in MCF rubber.

\section{Conclusions}

MCF rubber solar cells are made of rubber so that they will be elastic and extensible. Provided that the transparent glass used in fabrication is made of a flexible material such as a thin transparent polymer plate, the MCF rubber solar cells could also be flexible. To achieve flexibility and an effective photovoltaic effect, the constitution of the MCF rubber solar cells requires both soluble and insoluble rubbers, $\mathrm{Fe}_{3} \mathrm{O}_{4}, \mathrm{TiO}_{2}, \mathrm{Na}_{2} \mathrm{WO}_{4} \cdot 2 \mathrm{H}_{2} \mathrm{O}$, etc. On the basis of this required constitution, we propose a consummate fabrication process for MCF rubber solar cells by synthesizing: 1) a novel adhesion technique, 2) electrolytic polymerization of rubber mixed with water-soluble and water-insoluble rubbers, and 3) the permeation of liquid to rubber.

For the consummate fabrication process, we clarified that there exist photovoltaic effects of emulsifier PVA, insoluble rubber $\mathrm{Q}$, and metal complex hydrate $\mathrm{Na}_{2} \mathrm{WO}_{4} \cdot 2 \mathrm{H}_{2} \mathrm{O}$, which appear to be the same as the photovoltaic effects of water-soluble rubber. We clarified the photovoltaic effects of porous MCF rubber permeated by any liquid and of adhesive MCF rubber liquids. We also verified the effectiveness of our production procedure, in which MCF rubber that is electrolytically polymerized in advance is attached to $\mathrm{TiO}_{2}$-coated transparent glass and again electrolytically polymerized.

We investigated the $\gamma$-irradiation effect of the MCF rubber solar cells produced by our proposed consummate fabrication process. Whether or not $\gamma$-rays are irradiated, the photovoltage and current increase and the area of the hysteresis voltammogram curve are enhanced by ultraviolet light illumination. However, whether or not ultraviolet light is irradiated, the photovoltage and current decrease and the area of the hysteresis voltammogram curve are decreased by $\gamma$-irradiation. These tendencies might be deduced by synthesizing existing knowledge of the enhancement of the reverse-bias saturation current, the diode ideality factor, and the attenuation of photon energy.

\section{Acknowledgements}

This work was supported in part by JSPS KAKENHI Grant Number JP 18K04040 and by the Fukushima Innovation Coast Framework project "Namie Town Creation with Revitalizics using Risk Communication Engineering: for Realization of Innovation Coast Framework" in Japan. The authors would like to thank I. Yoda, member of the technical staff of the Cobalt-60 Irradiation Facility of the Laboratory for Advanced Nuclear Energy at the Tokyo Institute of Technology 
(Tokyo, Japan) for irradiation support.

\section{Conflicts of Interest}

The authors declare no conflicts of interest regarding the publication of this paper.

\section{References}

[1] Shimada, K., Ikeda, R., Kikura, H. and Takahashi, H. (2019) Development of Magnetic Compound Fluid Rubber Sensor for Practical Usage on $\gamma$-Irradiation and Energy Harvesting for Broad-Band Electromagnetic Waves. World Journal of Mechanics, 9, 205-231. https://doi.org/10.4236/wjm.2019.99014

[2] Shimada, K. and Saga, N. (2016) Mechanical Enhancement of Sensitivity in Natural Rubber Using Electrolytic Polymerization Aided by a Magnetic Field and MCF for Application in Haptic Sensors. Sensors, 16, 1521. https://doi.org/10.3390/s16091521

[3] Shimada, K., Miyazaki, T., Shibayama, A. and Fujita, T. (2003) Extraction of Magnetic Clusters Self-Assembled by a Magnetic Field. Smart Materials and Structures, 12, 297-303. https://doi.org/10.1088/0964-1726/12/2/318

[4] Shimada, K., Fujita, T., Oka, H., Akagami, Y. and Kamiyama, S. (2001) Hydrodynamic and Magnetized Characteristics of MCF (Magnetic Compound Fluid). Transactions of the Japan Society of Mechanical Engineers, Part B, 664, 3034-3040.

[5] Shimada, K. and Saga, N. (2017) Development of a Hybrid Piezo Natural Rubber Piezoelectricity and Piezoresistivity Sensor with Magnetic Clusters Made by Electric and Magnetic Field Assistance and Filling with Magnetic Compound Fluid. Sensors, 17, 1521. https://doi.org/10.3390/s17020346

[6] Shimada, K. (2018) Elastic MCF Rubber with Photovoltaics and Sensing for Use as Artificial or Hybrid Skin (H-Skin): 1st Report on Dry-Type Solar Cell Rubber with Piezoelectricity for Compressive Sensing. Sensors, 18, 1841.

https://doi.org/10.3390/s18061841

[7] Shimada, K. (2017) Enhancement of MCF Rubber Utilizing Electric and Magnetic Fields, and Clarification of Electrolytic Polymerization. Sensors, 17, 767. https://doi.org/10.3390/s17040767

[8] Yamaguchi, M. (2001) Radiation-Resistant Solar Cells for Space Use. Solar Energy Materials and Solar Cells, 68, 31-53. https://doi.org/10.1016/S0927-0248(00)00344-5

[9] Guo, H.L., Shi, L.F., Sun, Q., Zhang, Q.M., Wu, Y.Y., Xiao, J.D., Guo, B. and Zhang, Y.Q. (2019) Degradation of Up-Grown Metamorphic InGap/InGaAs/Ge Solar Cells by Low-Energy Proton Irradiation. Solar Energy Materials and Solar Cells, 191, 399-405. https://doi.org/10.1016/j.solmat.2018.11.033

[10] Tuzun, O., Altindal, S. and Oktik, S. (2008) Effects of Illumination and ${ }^{60} \mathrm{Co} \gamma$-Ray Irradiation on the Electrical Characteristics of Porous Silicon Solar Cells. Renewable Energy, 33, 286-292. https://doi.org/10.1016/j.renene.2007.05.019

[11] Feteha, M.Y., Soliman, M., Gomaa, N.G. and Ashry, M. (2002) Metal-InsulatorSemiconductor Solar Cell under Gamma Irradiation. Renewable Energy, 26, 113-120. https://doi.org/10.1016/S0960-1481(01)00102-1

[12] Dixit, V.K., Khamari, S.K., Manwani, S., Porwal, S., Alexander, K., Sharma, T.K., Kher, S. and Oak, S.M. (2015) Effect of High Dose $\gamma$-Ray Irradiation on GaAs P-I-N 
Photodetectors. Nuclear Instruments and Methods in Physics Research Section A, 785, 93-98. https://doi.org/10.1016/j.nima.2015.03.008

[13] Karatas, S., Turut, A. and Altindal S. (2005) Effects of ${ }^{60}$ Co $\gamma$-Ray Irradiation on the Electrical Characteristics of $\mathrm{Au} / \mathrm{n}-\mathrm{GaAs}$ (MS) Structures. Nuclear Instruments and Methods in Physics Research Section A, 555, 260-265.

https://doi.org/10.1016/j.nima.2005.09.017

[14] Bobby, A., Shiwakoti, N., Verma, S., Gupta, P.S. and Antony, B.K. (2014) Enhancement in Electrical Properties of $\mathrm{Au} / \mathrm{n}$-GaAs Schottky Diodes Exposed to ${ }^{60} \mathrm{Co}$ Gamma Rays. Materials Science in Semiconductor Processing, 21, 116-121. https://doi.org/10.1016/j.mssp.2014.01.039

[15] Li, Y., Ma, Y., Lin, W., Dong, P., Yang, Z.M., Gong, M., Bi, J.S., Li, B., Xi, K. and Xu, G.B. (2018) Study of $\gamma$-Ray Irradiation Influence on $\mathrm{TiN} / \mathrm{HfO}_{2} / \mathrm{Si} \mathrm{MOS}$ Capacitor by C-V and DLTS. Superlattices and Microstructures, 120, 313-318. https://doi.org/10.1016/j.spmi.2018.05.046

[16] Tugluoglu, N., Altindal, S., Tataroglu, A. and Karadeniz, S. (2004) Dielectric Properties in $\mathrm{Au} / \mathrm{SnO}_{2} / n$-Si (MOS) Structures Irradiated under ${ }^{60} \mathrm{Co} \gamma$-Rays. Microelectronics Journal, 35, 731-738. https://doi.org/10.1016/j.mejo.2004.06.004

[17] Card, H.C. and Rhoderick, E.H. (1971) Studies of Tunnel MOS Diodes I. Interface Effects in Silicon Schottky Diodes. Journal of Physics D: Applied Physics, 4, 1589. https://doi.org/10.1088/0022-3727/4/10/319

[18] Shimada, K., Kikura, H., Takahashi, H. and Ikeda, R. (2019) Novel Adhesion Technique Using Metallic or Non-Metallic Hydrous Oxide of Metal Complexes Involving Magnetic Compound Fluid Rubber under Electrolytic Polymerization and Magnetic Field for Producing Sensors. Sensors, 19, 689.

https://doi.org/10.3390/s19030689

[19] Shimada, K., Ikeda, R., Takahashi, H. and Kikura, H. (2019) Development of a Magnetic Compound Fluid Rubber Stability Sensor and a Novel Production Technique via Combination of Natural, Chloroprene and Silicone Rubbers. Sensors, 189, 3901. https://doi.org/10.3390/s19183901

[20] Shimada, K., Ikeda, R., Kikura, H. and Takahashi, H. (2020) Enhancement of Diversity in Production and Application Utilizing Electrolytically Polymerized Rubber Sensors with MCF: 1st Report on Consummate Fabrication Combining Varied Kinds of Constituents with Porous Permeant Stocking-Like Rubber. Sensors, 20, 4658. https://doi.org/10.3390/s20174658

[21] Schneider, J., Matsuoka, M., Takeuchi, M., Zhang, J., Horiuchi, Y., Anpo, M. and Bahnemann, D.W. (2014) Understanding $\mathrm{Tio}_{2}$ Photocatalysis: Mechanisms and Materials. Chemical Reviews, 114, 9919-9986. https://doi.org/10.1021/cr5001892

[22] Fujishima, A. and Honda, K. (1972) Electrochemical Photolysis of Water at a Semiconductor Electrode. Nature, 238, 37-38. https://doi.org/10.1038/238037a0

[23] Uslu, H., Yildirim, M., Altindal, S. and Durmus, P. (2012) The Effect of Gamma Irradiation on Electrical and Dielectric Properties of Organic-Based Schottky Barrier Diodes (SBDs) at Room Temperature. Radiation Physics and Chemistry, 81, 362-369. https://doi.org/10.1016/j.radphyschem.2011.12.029

[24] Seino, S., Kinoshita, T., Otome, Y., Maki, T., Nakagawa, T., Okitsu, K., Mizukoshi, Y., Nakayama, T., Sekino, T., Niihara, K. and Yamamoto, T.A. (2004) $\gamma$-Ray Synthesis of Composite Nanoparticles of Noble Metals and Magnetic Iron Oxides. Scripta Materialia, 51, 467-472. https://doi.org/10.1016/j.scriptamat.2004.06.003

[25] Zhang, X.J., Zhang, D.G., Ni, X.M., Chen, J. and Zheng, H.G. (2008) Synthesis of $\mathrm{Cu} / \mathrm{SiO}_{2}$ Composite Films via Gamma-Irradiation Route and Their Optical Absorp- 
tion Properties. Materials Research Bulletin, 43, 2421-2426.

https://doi.org/10.1016/j.materresbull.2007.07.031

[26] Shimada, K. (2018) Elastic MCF Rubber with Photovoltaics and Sensing on Hybrid Skin (H-Skin) for Artificial Skin by Utilizing Natural Rubber: Third Report on Electric Charge and Storage under Tension and Compression. Sensors, 18, 1853. https://doi.org/10.3390/s18061853

[27] El-Nahass, M.M., Zeyada, H.M., Abd-El-Rahman, K.F. and Darwish, A.A.A. (2007) Fabrication and Characterization of 4-Tricyanovinyl-N, N-Diethylaniline/ P-Silicon Hybrid Organic-Inorganic Solar Cells. Solar Ener. Mat. Solar Cells, 91, 1120-1126. https://doi.org/10.1016/j.solmat.2007.03.016

[28] Raslan, H.A., Saied, H.A.E., Mohamed, R.M. and Yousif, N.M. (2019) Gamma Radiation Induced Fabrication of Styrene Butadiene Rubber/Magnetite Nasnocomposites for Positive Temperature Coefficient Thermistors Application. Composites Part B: Engineering, 176, Article ID: 107326.

https://doi.org/10.1016/j.compositesb.2019.107326

[29] Afify, T.A., Ghazy, O.A., Saleh, H.H. and Ali, Z.I. (2018) Efficient in Situ Synthetic Routs of Polyaniline/Poly(Vinyl Alcohol)/ $\mathrm{TiO}_{2}$ Nanocomposites Using Gamma Irradiation. Journal of Molecular Structure, 1153, 128-134.

https://doi.org/10.1016/j.molstruc.2017.09.094

[30] Zhang, Z.R., Tang, X.B., Liu, Y.P., Xu, Z.H., Liu, K., Yuan, Z.C. and Chen, W. (2017) A Study on the Degradation of Dye-Sensitized Solar Cells Irradiated by Two Different Dose Rates of $\gamma$-Rays. Journal of Radioanalytical and Nuclear Chemistry, 312, 609-614. https://doi.org/10.1007/s10967-017-5262-6

[31] Huang, W., Yang, W., Ma, Q., Wu, J., Fan, J.H. and Zhang, K. (2016) Preparation and Characterization of $\gamma$-Ray Radiation Shielding $\mathrm{PbWO}_{4} / \mathrm{EPDM}$ Composite. Journal of Radioanalytical and Nuclear Chemistry, 309, 1097-1103. https://doi.org/10.1007/s10967-016-4713-9

[32] Chang, L., Zhang, Y., Liu, Y.J., Fang, J., Luan, W.L., Yang, X.M. and Zhang, W.D. (2015) Preparation and Characterization of Tungsten/Epoxy Composites for $\gamma$-Rays Radiation Shielding. Nuclear Instruments and Methods in Physics Research Section B, 356-357, 88-93. https://doi.org/10.1016/j.nimb.2015.04.062 


\section{Appendix}

The completed sensors shown in Figure A1(c) and Figure A1(d) consisted of MCF rubber liquid with complex hydrates as $1 \mathrm{~g}$ Ni powder, $0.75 \mathrm{~g} \mathrm{MF}$ (W-40), $3 \mathrm{~g}$ NR-latex, $3 \mathrm{~g}$ CR-latex (671A), and $0.5 \mathrm{~g}$ complex hydrates, and MCF rubber without complex hydrates as $3 \mathrm{~g}$ Ni powder, $0.75 \mathrm{~g}$ MF (W-40), $3 \mathrm{~g}$ NR-latex, and $3 \mathrm{~g}$ CR-latex $(671 \mathrm{~A})$, with a 1-mm metal plate gap, a constant electric field at $6 \mathrm{~V}, 2.7 \mathrm{~A}$ and $5 \mathrm{~min}$ under atmosphere, and a 312-mT magnetic field created by permanent magnets as paired opposites at each electrolytic polymerization [18].

Although ordinary solid rubber cannot be doped by any reagents directly because a solid rubber is generally impermeable, any liquid can permeate the electrolytically polymerized MCF rubber, as shown in Figure A2 [20]. Here, KF96 has $1000 \mathrm{cSt}$, MF has a W40. 312-mT magnetic field, and an electric field (30 V, $2.7 \mathrm{~A}, 5 \mathrm{~min}$ ) is applied with a $1-\mathrm{mm}$ electrode gap. Figure A2 shows water-soluble and combination water-soluble and water-insoluble MCF rubbers. In Figure A2(b) and Figure A2(d), water can be seen as a reflection on the rubber surface after permeation.

Whether the MCF rubber is made of water-soluble rubber or a combination of water-soluble and water-insoluble rubbers, by combining it with either metal complex hydrate $\mathrm{Na}_{2} \mathrm{WO}_{4} \cdot 2 \mathrm{H}_{2} \mathrm{O}$ or water, or by combining it with a mixture of the two, the MCF rubber becomes highly porous [20] (Figure A3).

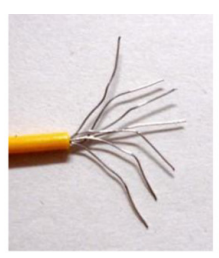

(a)

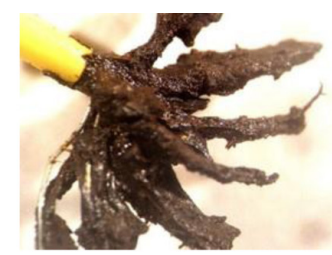

(b)

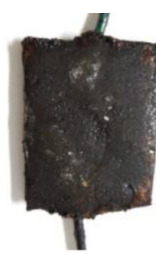

(c)

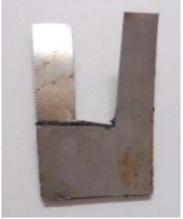

(d)

Figure A1. Photographs of wire-type and plate-type sensors: (a) electric wire as electrodes of wire-type sensors; (b) thin electric wires affixed to electrolytically polymerized MCF rubber with the complex hydrate; (c) completed MCF rubber wire-type sensor; (d) completed MCF rubber plate-type sensor [18].

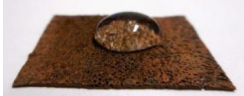

(a)

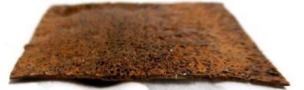

(b)

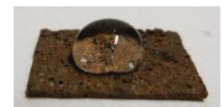

(c)

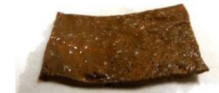

(d)

Figure A2. Images of MCF rubber before and after water permeation: (a) before permeation (0.75 g MF, $0.5 \mathrm{~g}$ TiO2, $3 \mathrm{~g} \mathrm{~S}-500,3 \mathrm{~g}$ 671A, $3 \mathrm{~g} \mathrm{Ni})$; (b) after permeation (0.75 g MF, $0.5 \mathrm{~g} \mathrm{TiO}_{2}$, $3 \mathrm{~g} \mathrm{~S}-500,3 \mathrm{~g}$ 671A, $3 \mathrm{~g} \mathrm{Ni}$ ); (c) before permeation (3 g KF96, 3 g PVA, $0.75 \mathrm{~g}$ MF, $0.5 \mathrm{~g} \mathrm{TiO}_{2}$, $3 \mathrm{~g} \mathrm{~S}-500,3 \mathrm{~g}$ 671 A, $3 \mathrm{~g} \mathrm{Ni}$ ); (d) after permeation (3 g KF96, 3 g PVA, 0.75 g MF, 0.5 g TiO $_{2}, 3$ g S-500, $3 g$ 671A, $3 \mathrm{~g} \mathrm{Ni}$ ) [20]. 


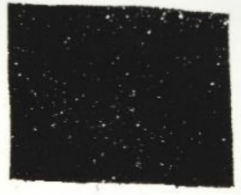

(a)

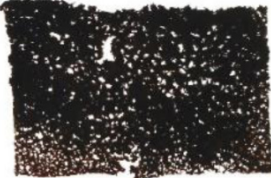

(b)

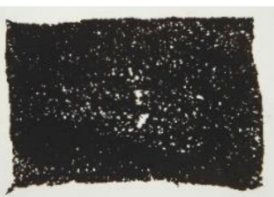

(c)

Figure A3. Panoramic images transmitted by light of the rubber facing, which was electrolytically polymerized once only, of a cathode electrode: (a) $0.5 \mathrm{~g} \mathrm{Na}_{2} \mathrm{WO}_{4} \cdot 2 \mathrm{H}_{2} \mathrm{O}, 0.75 \mathrm{~g}$ MF, $0.5 \mathrm{~g} \mathrm{TiO}_{2}$, $3 \mathrm{~g} \mathrm{~S}-500,3 \mathrm{~g} 671 \mathrm{~A}, 3 \mathrm{~g} \mathrm{Ni}$ (b) $0.5 \mathrm{~g} \mathrm{Na}_{2} \mathrm{WO}_{4} \cdot 2 \mathrm{H}_{2} \mathrm{O}, 3 \mathrm{~g}$ water, $0.75 \mathrm{~g} \mathrm{MF}$, $0.5 \mathrm{~g} \mathrm{TiO}_{2}$, 3 g S-500, $3 \mathrm{~g} 671 \mathrm{~A}, 3 \mathrm{~g} \mathrm{Ni}$; (c) $0.5 \mathrm{~g} \mathrm{Na}_{2} \mathrm{WO}_{4} \cdot 2 \mathrm{H}_{2} \mathrm{O}, 3$ g water, 3 g KF96 (1000 cSt), 3 g PVA, 0.75 g MF, 0.5 g TiO $_{2}$, 3 g S-500, 3 g 671A, 3 g Ni [20]. 